\title{
Expanding the Use of RNA in Forensic Science: A Quantum Dot Molecular Beacon Approach
}

\author{
Joshua R. Moore
}

Follow this and additional works at: https://researchrepository.wvu.edu/etd

\section{Recommended Citation}

Moore, Joshua R., "Expanding the Use of RNA in Forensic Science: A Quantum Dot Molecular Beacon Approach" (2015). Graduate Theses, Dissertations, and Problem Reports. 6253.

https://researchrepository.wvu.edu/etd/6253

This Thesis is protected by copyright and/or related rights. It has been brought to you by the The Research Repository @ WVU with permission from the rights-holder(s). You are free to use this Thesis in any way that is permitted by the copyright and related rights legislation that applies to your use. For other uses you must obtain permission from the rights-holder(s) directly, unless additional rights are indicated by a Creative Commons license in the record and/ or on the work itself. This Thesis has been accepted for inclusion in WVU Graduate Theses, Dissertations, and Problem Reports collection by an authorized administrator of The Research Repository @ WVU. For more information, please contact researchrepository@mail.wvu.edu. 


\title{
Expanding the Use of RNA in Forensic Science: A Quantum Dot Molecular Beacon Approach
}

\author{
Joshua R. Moore \\ Thesis submitted \\ to the Eberly College of Arts and Sciences \\ at West Virginia University \\ in partial fulfillment of the requirements for the degree of \\ Master of Science in \\ Forensic Biology \\ Committee Members: \\ Clifton P. Bishop, Ph.D., Chair \\ Stephanie T. Young, Ph.D. \\ Daniel G. Panaccione, Ph.D. \\ Department of Biology \\ Morgantown, West Virginia \\ 2015
}

Keywords: Quantum dot molecular beacons, body fluid identification, forensics, RNA Copyright 2015 Joshua R Moore 


\author{
Abstract \\ Expanding the Use of RNA in Forensic Science: \\ A Quantum Dot Molecular Beacon Approach
}

Joshua R. Moore

As the popularity of shows such as CSI increases, so does the demand for DNA evidence in court cases. This has led to the overwhelming of capacity for analysis of biological samples at crime labs across the country, and to the development of a massive backlog of DNA evidence waiting to be processed. At the end of 2011, labs had a processing capacity of 250,000 cases per year, but an annual total of nearly 350,000 that needed to be processed. Such delays have effects throughout the US justice system. One way to reduce the backlog would be to increase the value of the evidence retrieved from the scene, reduce the collection of unnecessary evidence, and retrieve as much data from the evidence as possible in the fewest steps. We investigated a novel, confirmatory method of body fluid identification using quantum dot molecular beacons (QDMBs). The QDMBs target RNA species that are tissue-specific or sex-specific, allowing for the identification of body fluid stains and identifying the sex of the depositor of a bloodstain. Our results show that we were successful in developing QDMBs that identify blood, semen, saliva, male blood, and female blood, along with a human-specific beacon. We were also able to detect aged stains, although the age detectable is dependent upon the particular fluid tested. This technique has a low cost, confirmatory testing, and a high potential for portability, meaning it could be performed at the scene to increase the value of evidence retrieved. In addition to being a confirmatory test, it does not lead to the degradation of DNA, as can some presumptive tests. We believe this technique holds great potential for increasing the value of RNA in forensic evidence and helping to reduce the biological evidence backlog. 


\section{Acknowledgements}

I would like to thank first Dr. Clifton Bishop, my advisor. You have provided much guidance and support personally and professionally, and I feel I have grown considerably as a scientist and a person during my time in your lab. While the research has had its ups and downs, I knew I always had your support. Special thanks go to Dr. Stephanie Young for starting the research on the molecular beacons, and giving me a solid foundation upon which to perform my research. I also wish to thank Dr. Daniel Panaccione as my third committee member, and a professor whose class I greatly enjoyed. Your guidance has been helpful, particularly as a voice from outside of the field of forensic science.

I would like to thank my lab partner Amanda Balasko, for her assistance on this project and her help as one of many donors that made the research possible. You have been a great support, and in training you I learned even more about the research.

In addition, I would like to thank the faculty, staff, and graduate students of the Department of Biology. None of this would be possible without you.

Finally, I want to thank my friends and family for all their support and love over the years. This has not always been an easy road, but I have always known I had your support. 


\section{Table of Contents}

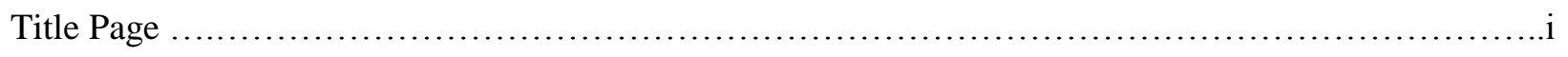

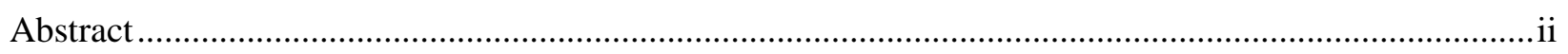

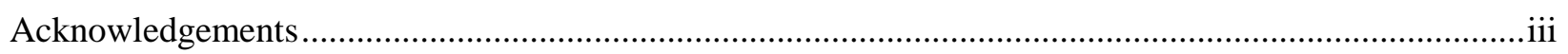

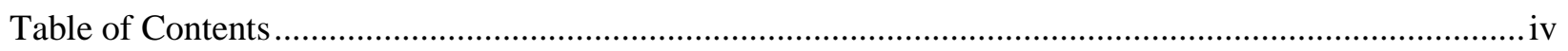

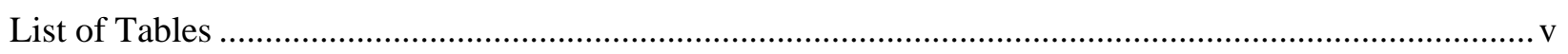

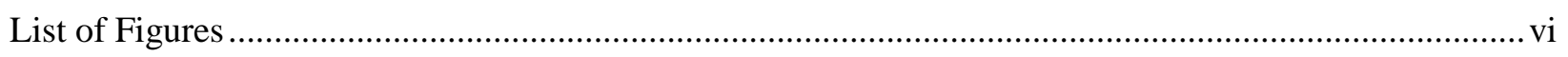

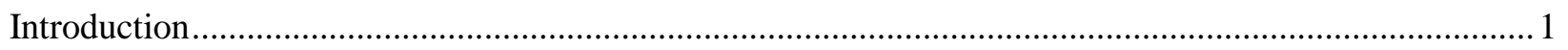

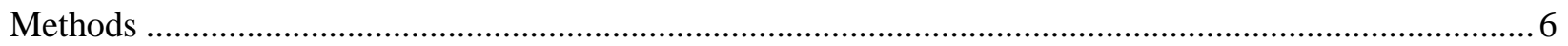

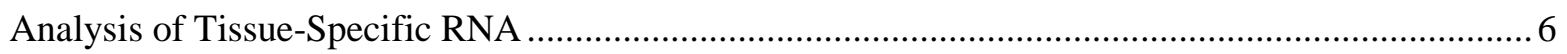

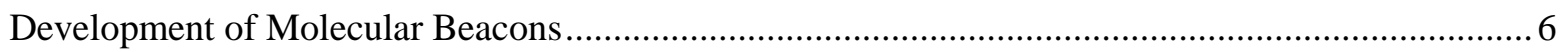

Conjugation of Molecular Beacons to Quantum Dots ...................................................................... 7

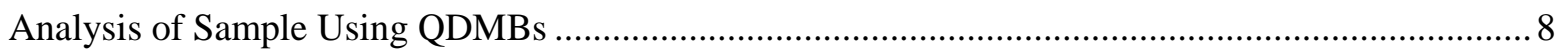

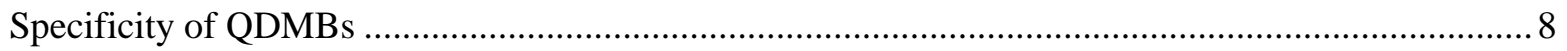

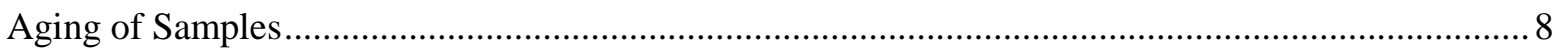

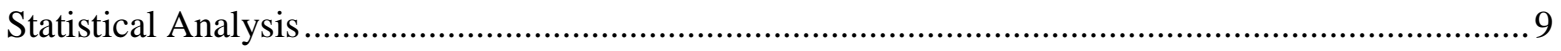

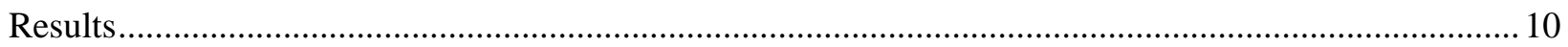

PCR Verification of Body Fluid Specificity ....................................... Error! Bookmark not defined.

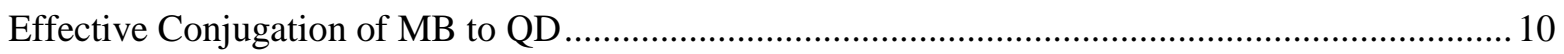

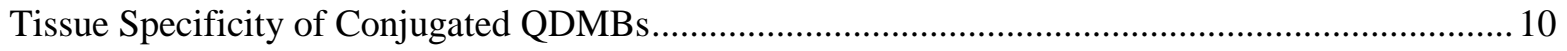

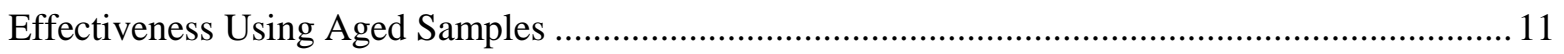

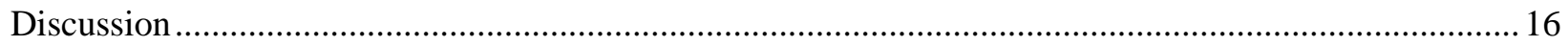

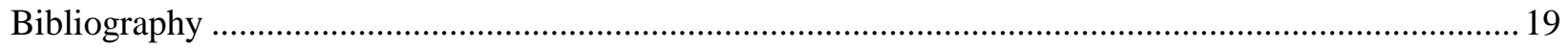

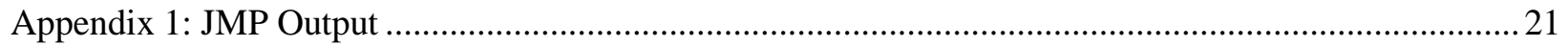




\section{List of Tables}

Table 1: Fluorescence values for organic flurophores versus quantum dots. ............................................... 5

Table 2: RNA identities and primer sequences for body fluid identification. ......................................... 9

Table 3: Body fluid specific RNA identities with QD wavelength, quencher, and beacon sequence. .........9 


\section{List of Figures}

Figure 1: A traditional molecular beacon and its functioning. GeneLink, 2015 ........................................ 5

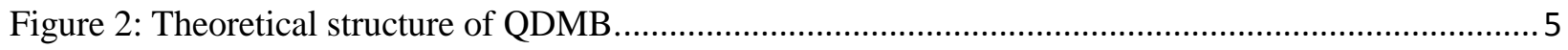

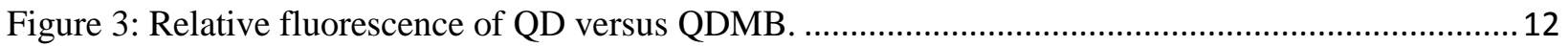

Figure 4: Tissue specificity testing of QDMBs................................................................................. 13

Figure 5: A comparison of target and non-target QDMB fluorescence expression................................... 14

Figure 6: Results of aging of samples, tested with tissue-specific beacon. ............................................ 14

Figure 7: The JMP output for ANOVA analysis of the female-specific beacon testing data.................... 15 


\section{Introduction}

The field of forensic science, and DNA analysis in particular, has grown substantially in recent years due to advancements in the technologies used for forensic analyses. Likewise, there has been an increase in the amount of evidence collected by crime scene investigators and thus an increase in the amount of evidence in need of processing by forensic laboratories. The amount of evidence collected and the amount of evidence that can be processed in a given period of time have both grown, but at unequal rates, leading to a substantial backlog of evidence waiting for processing (1). As this backlog grows, cases take longer to be investigated, trials are delayed, and the criminal justice system slows. As of 2011, US labs had the capacity to process almost 250,000 cases, but had a total DNA case load of almost 350,000 cases. Although the labs are increasing their capacity they are still being outpaced by the growth in demand for casework services (1).

There are multiple ways to reduce this backlog and increase the rate at which evidence is processed. Some methods include: increasing the employment numbers at crime laboratories to increase the volume that can be processed at a given lab; improving the techniques used to analyze the evidence such that results can be obtained in a more efficient manner; or, developing a method of ensuring only the evidence of highest value is retrieved from the scene and processed at the crime laboratory $(1,2)$.

This research explores a possible answer using that third method, of increasing the value of evidence retrieved and analyzed. If confirmatory testing is performed in the field, less analysis time in the lab will be wasted on preliminary steps, and processing time and effort will be saved. A portable technology that gives a confirmatory, rather than presumptive, answer to the identity 
of a body fluid stain and confirms the presence of nucleic acids useful for further analysis would be of great value. This would increase the value of evidence retrieved and allow field investigators to reject samples that add little or no value to the investigation.

The focus of this research is on body fluid stains, as they are likely to contain DNA evidence that can be used to identify suspects and connect a suspect to the scene or to the victim. It is true that many tests for certain body fluids already exist, but there are not confirmatory tests for each body fluid $(3,4)$. Also, many of these confirmatory tests can only be performed in an equipped forensic lab and not in the field (4-7). Portable presumptive tests may give false positives, or worse, false negatives for body fluids. Additionally, some presumptive tests have negative effects on the stains, affecting the DNA results later in the process (8). This could result in waste of analysts' time through the necessity of further confirmatory testing or the rejection of evidence due to it being falsely believed a non-body-fluid stain with no relevance to the investigation. And at the time of this writing, there is no confirmatory test for the presence of saliva $(3,4)$.

One way to develop a confirmatory method of body fluid identification would be to look for molecular species that are unique to a particular body fluid. While DNA can provide individually-identifiable information for evidence, it is almost universally present in tissues and cannot provide information on the body fluid source of a stain. RNA, on the other hand, is generally present in much higher concentrations than DNA and has variability based on tissue identity. Additionally, RNA can be co-isolated with DNA, reducing consumption of the evidence and potentially increasing the speed of the workflow $(9,10)$. Using a confirmatory technique that relies on nucleic acids avoids the risk of presumptive techniques that would degrade the sample, saves valuable analyst time, and helps increase the rate at which a case can be processed. 
Thus, the goal of identifying a stain could be achieved through the use of RNA species that are only expressed in a given body fluid, or have alternatively-spliced variants that are processed differently for a given body fluid. Tissue-specific RNA species have been used previously for body fluid identification (11-13). The caveat to these past techniques is that they rely on polymerase chain reaction (PCR) for identification of the tissue-specific RNA species. PCR is highly useful and accurate in the identification of body fluids, but it also requires specialized equipment and training, and is a time-consuming process.

Another method of identifying these tissue-specific RNA species would be to use a particular kind of probe that only binds and fluoresces in the presence of a target RNA species. Molecular Beacons (MB) are a form of nanotechnology that can function as this type of probe. MBs are short sequences of DNA or RNA designed to bind to a target sequence and that have a quencher or fluorophore on either end and small flanking sequences that result in self-folding into a hairpin shape (Figure $1 ; 14)$. These MBs are stable in this hairpin shape and do not fluoresce, but if mixed with the target RNA they will unfold, bind the target, and produce a positive signal in the form of fluorescence. If, however, the molecular beacon is mixed with a non-target RNA, it stays in the hairpin shape and reveals no increased fluorescence.

Specifically, the proposed MBs use a quantum dot (QD) fluorophore. QDs were chosen because they have a much higher fluorescence than traditional organic fluorophores, and are highly stable as well $(15,16)$. The specific quantum dots used have a CdSe core with a $\mathrm{ZnS}$ coating. The wavelength of fluorescence is based on the size of the CdSe core, and the intensity of the fluorescence increases with the wavelength (Table 1;17). This product would be known as a quantum dot molecular beacon (QDMB), to be distinguished from traditional MBs; the theoretical structure is given in Figure 2. 
This reaction between the QDMB and the target RNA occurs at room temperate in a short amount of time and requires only a small fluorospectrometer and a laptop for determination of the response. If combined with a fast spin-column extraction technique, analysis of potential body fluids resulting in a confirmatory response can occur in as little as 30 minutes. Such a technique would also require only a minimum of training compared to PCR-based analysis. As such, it is believed this holds great potential for increasing the value of evidence retrieved by ensuring that evidence collected and returned to the crime laboratory is of actual scientific value.

This evidentiary value can be increased further if greater information is able to be retrieved from the sample using the same technique. It has been established that tissue-specific RNA species can be used for body fluid identification, but there may be more information that can be derived from the RNA in the stains. For instance, if the sex of the 'donor' could be determined at the scene, this may provide an investigative lead and will give more information to direct the continued processing of the evidence. This method also has the potential for detecting mixtures of fluids, which can affect the later processing as well.

The main objective of this thesis is to refine past research upon QDMBs for body fluid identification and to expand their usefulness as a forensic analytical technique. A rapid test for body fluid identification and determination of sex of the person that deposited the stain may be a great boon to investigators by helping narrow down which evidence may be of the highest value to the investigation. The preliminary detection limitations of this technique were also tested, through a dilution series and the aging of samples. 


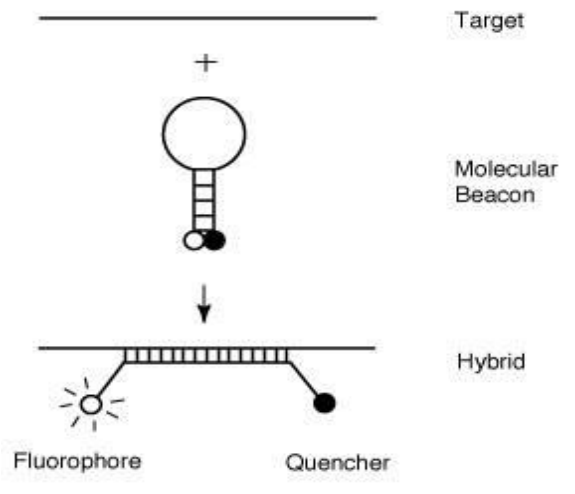

Figure 1: A traditional molecular beacon and its method of function. Upon 'discovery' of its target sequence, it is more stable to unfold from the hairpin and bind to the target, resulting in fluorescence. GeneLink, 2015.

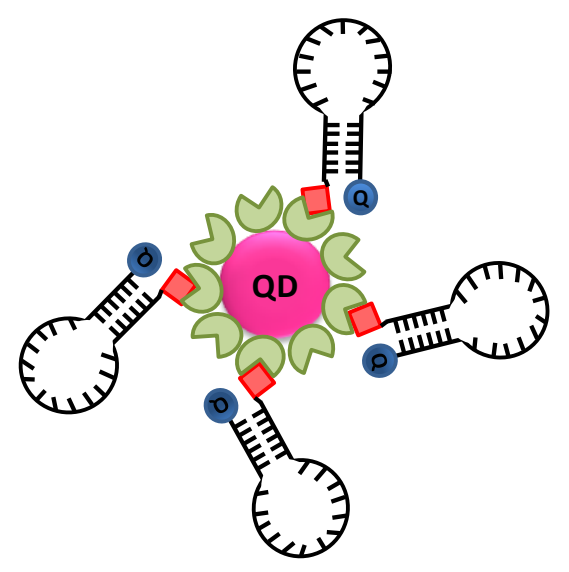

Figure 2: Theoretical structure of QDMB. Note the multiple quenchers attached to the $Q D$ fluorophore. The red box represents biotin and the green shapes are the streptavidin, which are responsible for the conjugation. Courtesy of Dr. Stephanie Young.

Table 1: Fluorescence values for organic fluorophores versus quantum dots.

\begin{tabular}{|l|l|l|}
\hline Fluorophore & $\begin{array}{l}\text { Emission } \\
\text { Wavelength }\end{array}$ & $\begin{array}{l}\text { Extinction } \\
\text { Coefficient } \\
(\mathbf{n m})\end{array}$ \\
\hline $\left.\mathbf{M A M}^{-\mathbf{1}} \mathbf{c m}^{-\mathbf{1}}\right)$ \\
\hline Texas Red $^{[18]}$ & 525 & 74,850 \\
\hline QD525 $^{[19]}$ & 583 & 136,000 \\
\hline QD800 $^{[19]}$ & 525 & 710,000 \\
\hline
\end{tabular}




\section{Methods \\ Analysis of Tissue-Specific RNA}

The development of this methodology began with the identification of tissue-specific RNAs. An extensive review of the literature was undertaken to choose candidate genes that display tissue-specific expression or tissue-specific alternative splice variants. After selection of candidate genes, PCR primers were designed to confirm the tissue-specificity of the RNA. If an mRNA was found to not be tissue specific, it was rejected, and the literature search continued. This was repeated until a tissue-specific RNA was found for each body fluid or subject of interest (Table 2).

The blood, saliva, and human-specific beacons were developed as part of past research in the Bishop lab (26). The rationale for their selection was based on published data and the citations are included in Table 2. The male-specific beacon was originally believed to be semenspecific, but further testing showed that the gene variant selected, originally thought to be a splice variant only found in testes, is also found in male blood. XIST was chosen as the femalespecific beacon due to its role in the $\mathrm{X}$-inactivation process and recent research showing that it is significantly upregulated in the female blood transcriptome $(24,25)$.

\section{Development of Molecular Beacons}

Once target RNAs were chosen, molecular beacons were designed based on those RNAs. The MBs were designed to target exon junctions so that the beacons would not bind DNA instead and thus no longer be tissue-specific. Lengths of 20-25 nt were chosen, similar to PCR primers, as this length provides specificity and stability to the target-beacon complex. The short flanking sequences were then added to allow self-folding, but they are sufficiently short such that it is more thermodynamically stable for the target-beacon complex to form when the target RNA 
is present. Molecular beacons were synthesized according to established protocols for streptavidin-biotin-linked MBs with few modifications (27).

2'-O-Methyl-RNA oligonucleotides modified with an Iowa Black quencher on the 3' end and a 5' biotin linker were obtained from Integrated DNA Technologies (Coralville, IA). The sequence of each oligonucleotide was designed to incorporate the complementary sequence of the forward primer used in the previous PCR--based screen, and these sequences can be found in Table 3. Six nucleotides of complementary sequence were designed to flank either end of the oligonucleotide to create the stem portion of the MB. Streptavidin-coated QDs were obtained from Life Technologies (Carlsbad, CA). The RNA species, the emission wavelengths of the QD label, and the corresponding quencher molecule used for each body fluid can be found in Table 3.

\section{Conjugation of Molecular Beacons to Quantum Dots}

As the molecular beacon oligos were received from a different source than the quantum dot fluorophores, they needed to be conjugated in the lab. This conjugation technique was a modification of the technique used by Cady (27). Twenty-five pmol of the chosen QD, $1 \mathrm{mmol}$ of the MB oligo, and QD incubation buffer to a final volume of $400 \mu \mathrm{L}$ were combined in a sterile $1.5 \mathrm{~mL}$ tube. This mixture was incubated at room temperature for one hour. A Millipore Amicon 50K spin-column membrane was wet by adding $100 \mu \mathrm{L}$ of QD buffer and running in a centrifuge at 13,000 $\mathrm{xg}$ for 1 minute. The flow-through of this step was discarded. Once the incubation was complete, the $400 \mu \mathrm{L} \mathrm{QD} /$ oligo mixture was added to the Millipore spin column, and centrifuged at 13,000 xg for 5 minutes. This flow-through was reserved for fluorescence analysis. The flow-through was analyzed on the fluorospectrometer to test for any fluorescence which would indicate loss of QDs in the conjugation process; if no fluorescence is seen then the 
conjugation is highly efficient. The spin column was washed twice using $400 \mu \mathrm{L}$ of the buffer, and centrifuged at 13,000 xg for 5 minutes each time. The spin column was placed upside-down in a collection tube, and centrifuged at $1000 \mathrm{~g}$ for 2 minutes to collect the QDMBs. A significant reduction of fluorescence was observed between the QD and the conjugated QDMB, as the conjugation was successful.

\section{Analysis of Sample Using QDMBs}

For analysis of a sample, $20 \mu \mathrm{L}$ of RNA was combined with $2 \mu \mathrm{L}$ of the QDMB solution and incubated for 10 minutes. This mixture was analyzed by pipetting $2 \mu \mathrm{L}$ onto the pedestal of the NanoDrop 3300 (ThermoScientific). The blank for analysis was $2 \mu \mathrm{L}$ nuclease-free water, the background fluorescence was established using $2 \mu \mathrm{L}$ QDMB in $20 \mu \mathrm{L}$ water, and the positive control was $2 \mu \mathrm{L}$ of unquenched QD in $20 \mu \mathrm{L}$ water.

\section{Specificity of $Q D M B S$}

Each QDMB was tested for specificity by combining QDMBs with fresh RNA extracted from blood, semen, and saliva. Extractions were performed using the manufacturer's protocol for TRI-Reagent BD, using $30 \mu \mathrm{L}$ of the given body fluid (MRC, Inc., Cincinnati, OH). Once extracted, the RNA was analyzed using the protocol given above.

\section{Aging of Samples}

As the initial step in determining limits of detection for this technique, samples of each body fluid (blood, semen, and saliva) were deposited upon fabric, allowed to dry, and aged for a predetermined time period in the lab under ambient conditions. Samples were aged for 0, 1, 3, 7, or 14 days, then RNA was extracted and tested as described previously. 


\section{Statistical Analysis}

Results of each step were analyzed using one-way ANOVA followed by Tukey-Kramer

HSD, to test whether that there was a significant difference between positive and negative results

with each beacon. ANOVA including Dunnet's test was performed for the data of the aging

study, as this will show the significance relative to a control.

Table 2: RNA identities and primer sequences for body fluid identification.

\begin{tabular}{|c|c|c|c|}
\hline Body Fluid & RNA & $\begin{array}{c}\text { RNA } \\
\text { Alternatively } \\
\text { Spliced? }\end{array}$ & Primer Sequence \\
\hline Blood & $4.1 \mathrm{R}^{[20]}$ & Yes & $\begin{array}{l}\text { FP: 5'- AGCATGGAAGAAAAAGAGAGAAAGA -3' } \\
\text { RP: 5'- TCTTCACCAGGGGAGGTCCT -3' }\end{array}$ \\
\hline Saliva & $\mathrm{EMP}^{[21]}$ & No & $\begin{array}{l}\text { FP: 5'- ACCCTTCAGAACTCTCTTTGCTCA -3' } \\
\text { RP: 5'- AACGCCGATGATGAAGCTG -3' }\end{array}$ \\
\hline Semen & $\mathrm{SG}^{[22]}$ & No & $\begin{array}{l}\text { FP: 5'-ATGGGACAAAAAGGTGGATCA -3' } \\
\text { RP: 5'- GACTTTTTCGGGACTGGTCA -3' }\end{array}$ \\
\hline Male-specific & hHK $1^{[23]}$ & Yes & $\begin{array}{l}\text { FP: 5'- GCAAGGACAGTGCGTTCAAGA -3', } \\
\text { RP: 5'- CCGCATGGCATAGAGATACTTG -3' }\end{array}$ \\
\hline Female-specific & $\mathrm{XIST}^{[24,25]}$ & No & $\begin{array}{l}\text { FP: 5'- CTCTTTAGAATACTGATCCCATT -3' } \\
\text { RP: 5'- CTCCACCTAGGGATCGTCAA -3' }\end{array}$ \\
\hline $\begin{array}{l}\text { Blood/Saliva/Semen } \\
\text { (Human-Specific) }\end{array}$ & $\beta$-actin ${ }^{[26]}$ & No & $\begin{array}{c}\text { FP: 5'- CCATCCATGTACGTTGCTATCCAGGCTGT -3' } \\
\text { RP: 5'- GCAGCCGTGGCCATCTC -3' }\end{array}$ \\
\hline
\end{tabular}

Table 3: Body fluid specific RNA identities with QD wavelength, quencher, and beacon sequence. The underlined portion represents the self-complementary stem that leads to the formation of the molecular beacon hairpin structure.

\begin{tabular}{|c|c|c|c|}
\hline RNA & QD & $\begin{array}{c}\text { Iowa } \\
\text { Black } \\
\text { Quencher }\end{array}$ & MB Oligonucleotide Sequence \\
\hline $4.1 \mathrm{R}$ & $585 \mathrm{~nm}$ & FQ & 5'- CCCGGAUCUUUCUCUCUUUUUCUUCCAUGCUUCCGGG -3' \\
\hline EMP1 & $605 \mathrm{~nm}$ & RQ & 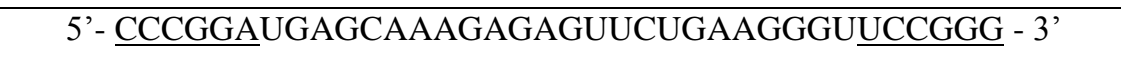 \\
\hline SG & $585 \mathrm{~nm}$ & FQ & 5'- CCCGGAAUGGGACAAAAAGGUGGAUCAUCCGGG - 3' \\
\hline hHK1 & $655 \mathrm{~nm}$ & RQ & 5'- CCCGGAUCUUGAACGCACUGUCCUUGCUCCGGG - 3' \\
\hline XIST & $625 \mathrm{~nm}$ & RQ & 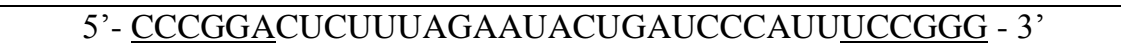 \\
\hline$\beta$-actin & $565 \mathrm{~nm}$ & FQ & 5'- $\underline{\text { CCCGGAACAGCCUGGAUAGCAACGUACAUGGCUGGUCCGGG - }}$ ' \\
\hline
\end{tabular}




\section{Results}

\section{Effective Conjugation of $M B$ to $Q D$}

The attachment of the biotinylated MB containing an Iowa Black quencher molecule to the streptavidin-coated QD resulted in a reduction of fluorescence. Effective conjugation is demonstrated in Figure 3, where a reduction in fluorescence of the QDMB is demonstrated relative to the QD alone. The semen QDMB showed the greatest level of quenching, with a 93\% reduction in fluorescence. The blood QDMB showed the lowest level of quenching, with a reduction in fluorescence of 55\%. The saliva and human-specific QDMBs showed a 64\% and $66 \%$ reduction in fluorescence, respectively. The female QDMB showed 87\% quenching, while the male QDMB displayed 82\% quenching effectiveness.

\section{Tissue Specificity of Conjugated QDMBS}

The QDMBs only showed a significant increase in fluorescence when combined with their appropriate target RNA and did not show a significant increase when combined with nontarget RNA species (Fig. 4). This demonstration of increasing fluorescence when only in contact with target RNA species can also be seen in Figure 5, where error bars are included. It should be noted that the sex-specific beacons did not identify saliva. Saliva is not separated by sex because the sex-specific beacons do not give a response to saliva. For this study, $n=14$ saliva donors, 7 female blood donors, 7 male blood donors, and 4 semen donors.

An ANOVA analysis with Tukey-Kramer HSD was also performed on the data, to provide statistical support for the conclusions observed. Each beacon tested resulted in a p-value of $<0.0001$ in the ANOVA for a positive response, when compared to non-target background 
fluorescence. The analytical results of the statistical analysis for the female-specific beacon are provided as an example of the output (Figure 6). The other analytical outputs can be found in Appendix 1.

\section{Effectiveness Using Aged Samples}

Results were mixed for the testing of effectiveness with aged samples. Blood and saliva were only detectable for 3 days, based on the design of the study. Semen was detectable for 7 days. The male and female beacons were both detectable in blood at 14 days; they may persist longer but the study only contained samples for 14 days of testing. It is of note that the male beacon displayed an upward trend in the fluorescence level with the length of time of aging of the sample. This may be coincidence, or an effect of the aging process. It should also be noted that the male and female beacons were used to test aged blood samples, and not stains of other fluids. For this study, n=3 samples from one donor per fluid per day.

The statistical analysis of the aged samples supports the conclusions reached from the graphing. The female-specific and male-specific beacons displayed a p-value of $<0.0001$ for each aging period, when compared to the control in ANOVA. The blood-specific beacon displayed a

p-value of $<0.0001$ for days 0,1 , and 3, while days 7 and 14 were not significantly different from the control, meaning a negative response. The semen-specific beacon displayed a p-value of $<0.0001$ for days $0,1,3$, and 7 , while day 14 was not significantly different from the control. The saliva-specific beacon displayed a p-value of $<0.0001$ for days $0,1,3$, and 7 , while day 14 was not significantly different from the control. The caveat to this is that while day 7 was significantly different from the control, it was actually due to lower RFU readings, still meaning a negative response. The full results can be found in Appendix 1. 

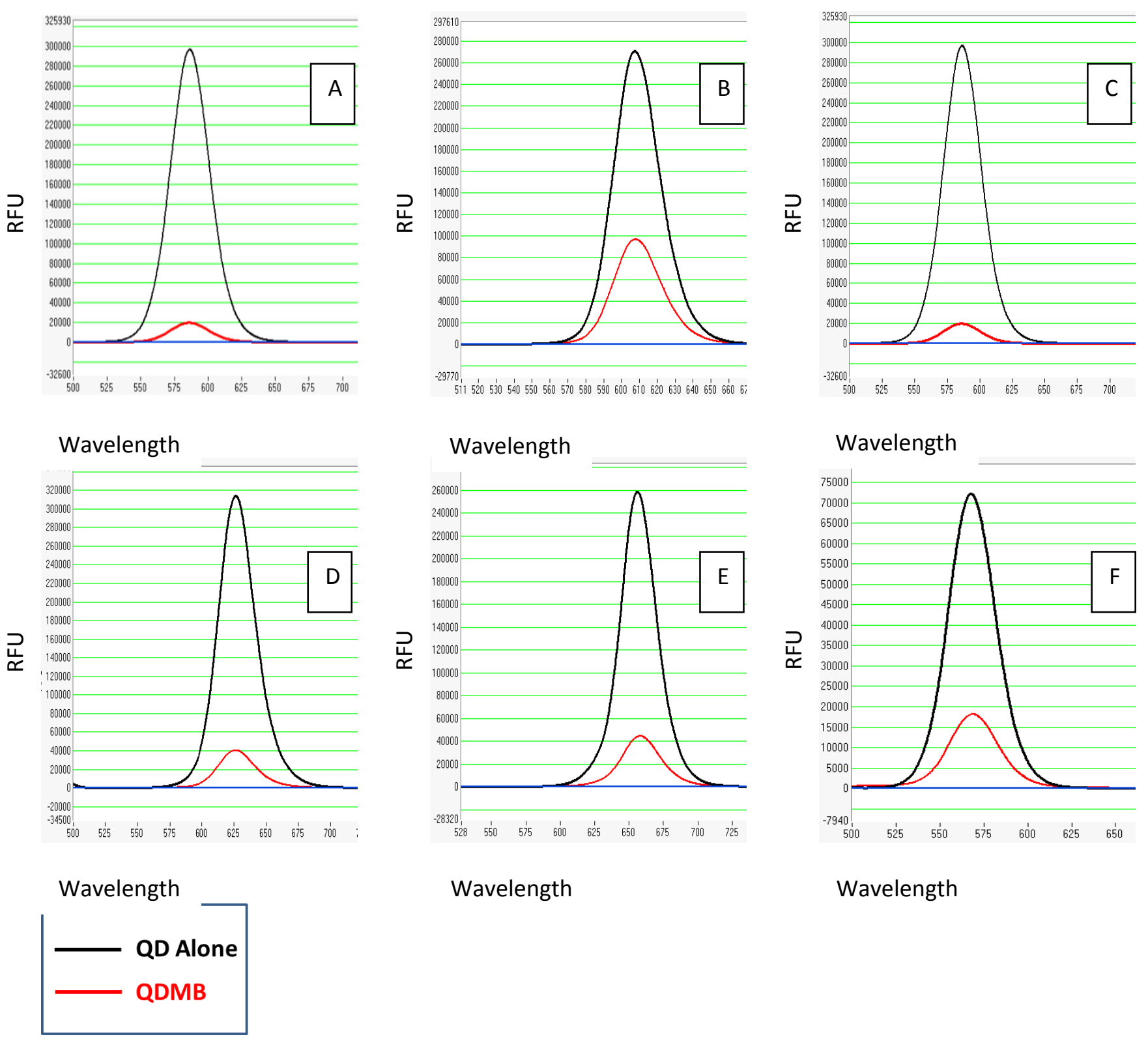

\section{Wavelength}

Wavelength

Figure 3: Relative fluorescence of $Q D$ versus $Q D M B$. The relative fluorescence of each $Q D$ (in black) is compared to that of the $Q D$ when conjugated to form the QDMB. A: Blood, B: Saliva, C: Semen, D: Female, E: Male, F: Human. 


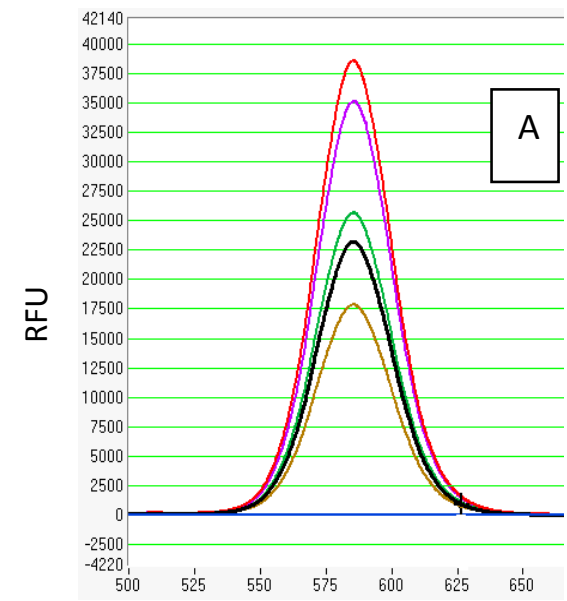

Wavelength

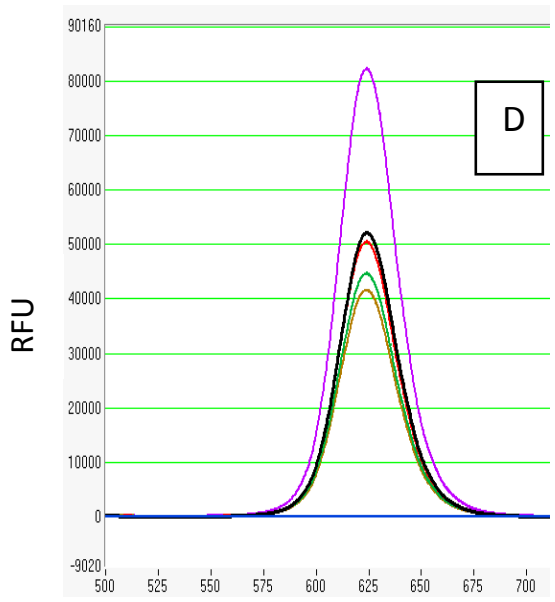

Wavelength

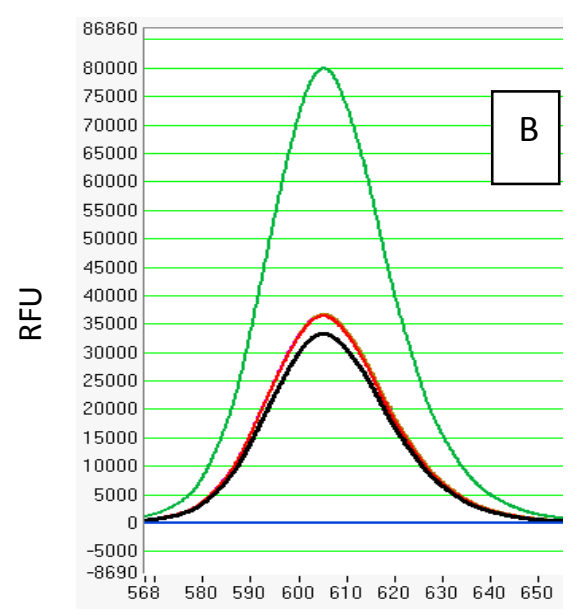

Wavelength

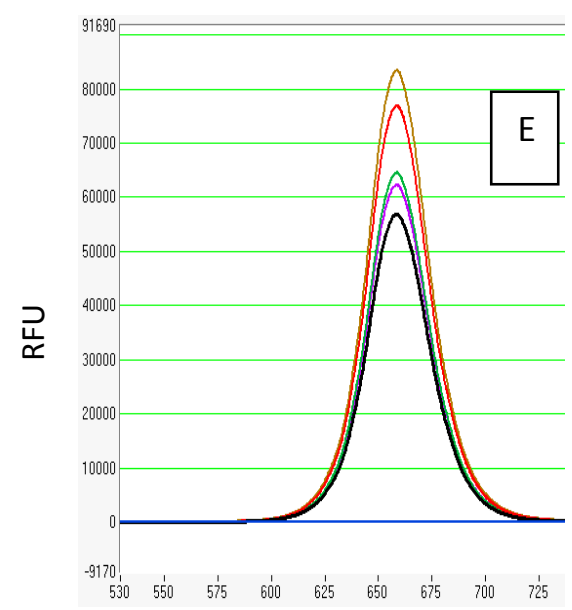

Wavelength

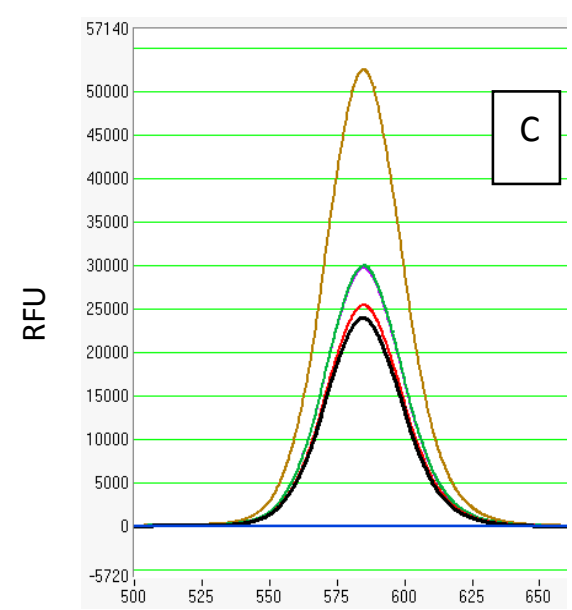

Wavelength

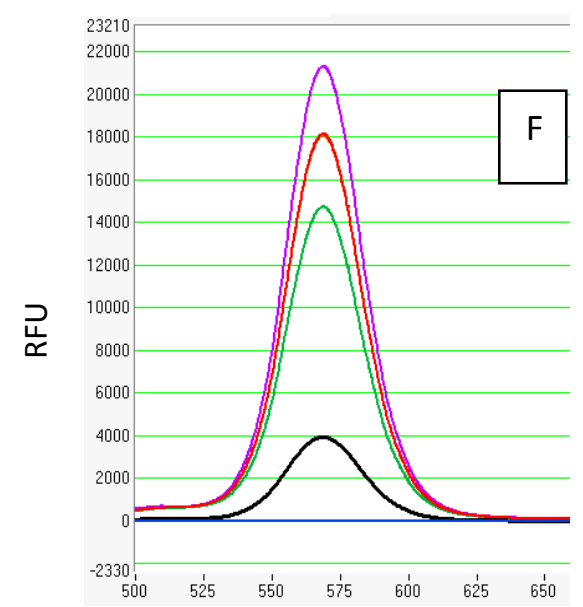

Wavelength

\section{- QDMB Alone \\ QDMB + Male \\ - Blood RNA \\ - QDMB + Saliva RNA \\ - QDMB + Semen RNA \\ Q QDMB + Female \\ Blood RNA}

Figure 4: Tissue specificity testing of QDMBs. These graphs demonstrate that the QDMBs only give fluorescence increases above background when in contact with RNA from the target body fluid. A: Blood, B: Saliva, C: Semen, D: Female, E: Male, F: Human. $N=14$ saliva donors, 7 female blood donors, 7 male blood donors, 4 semen donors. 


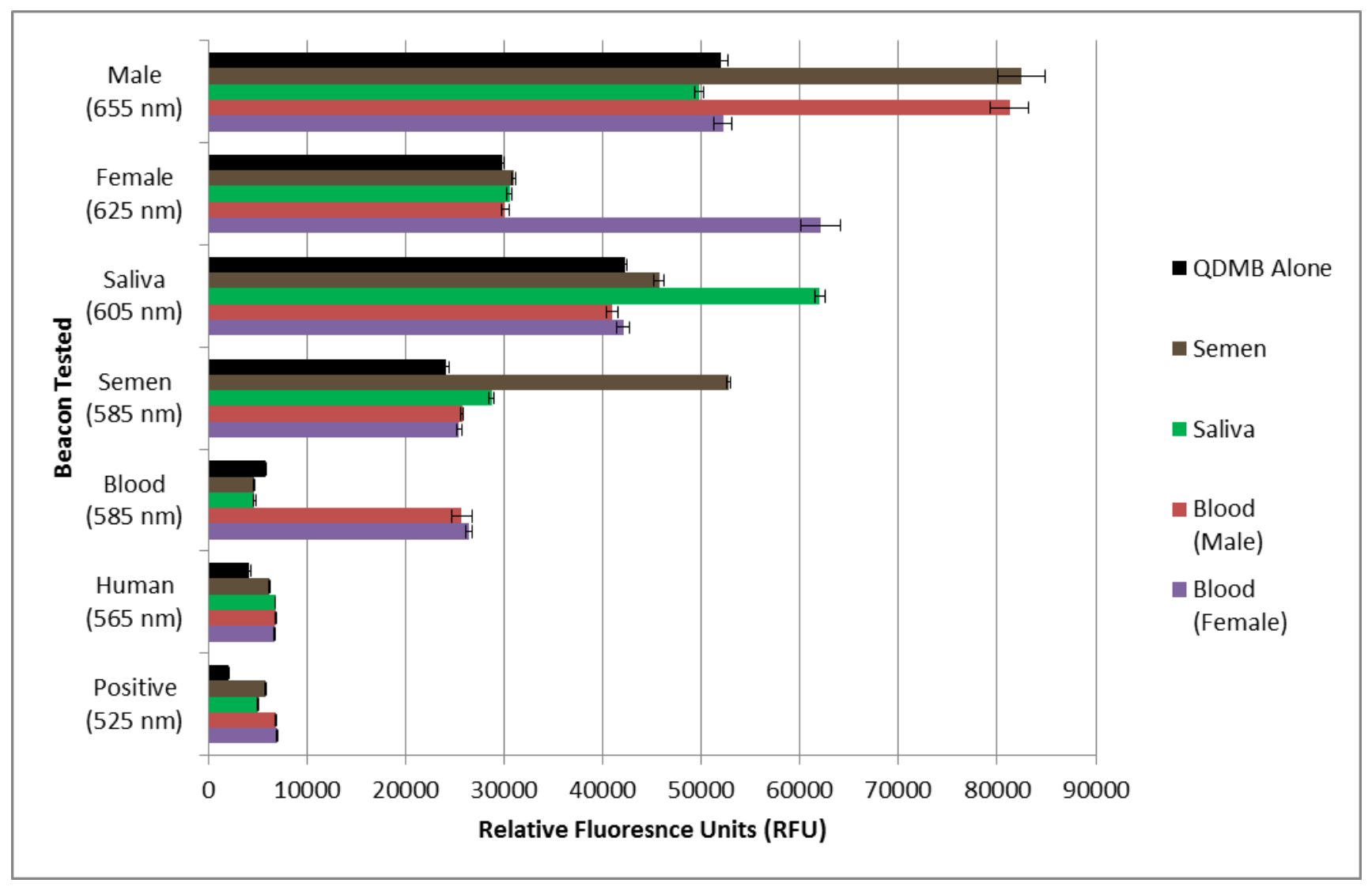

Figure 5: A comparison of target and non-target QDMB fluorescence expression. The QDMB displays a significant increase in fluorescence only when combined with the target RNA, and shows little or no increase relative to background when combined with non-target RNA. $N=14$ saliva donors, 7 female blood donors, 7 male blood donors, 4 semen donors. $P<0.0001$ for each positive result, as determined by ANOVA (See Figure 7 and Appendix).

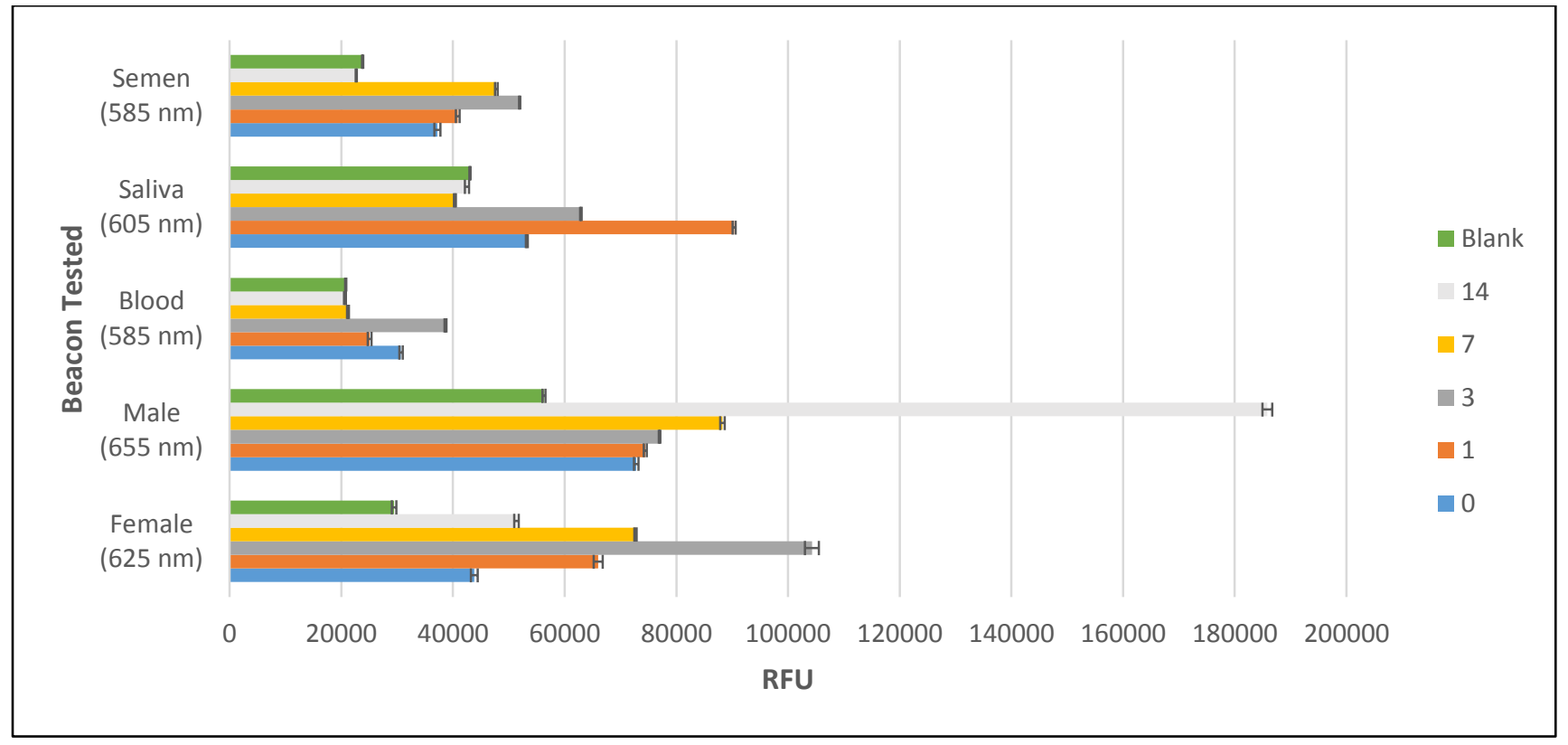

Figure 6: Results of aging of samples in days, tested with tissue-specific beacon. $N=3$ samples from one donor per fluid per day. $P$-values reported in text. 


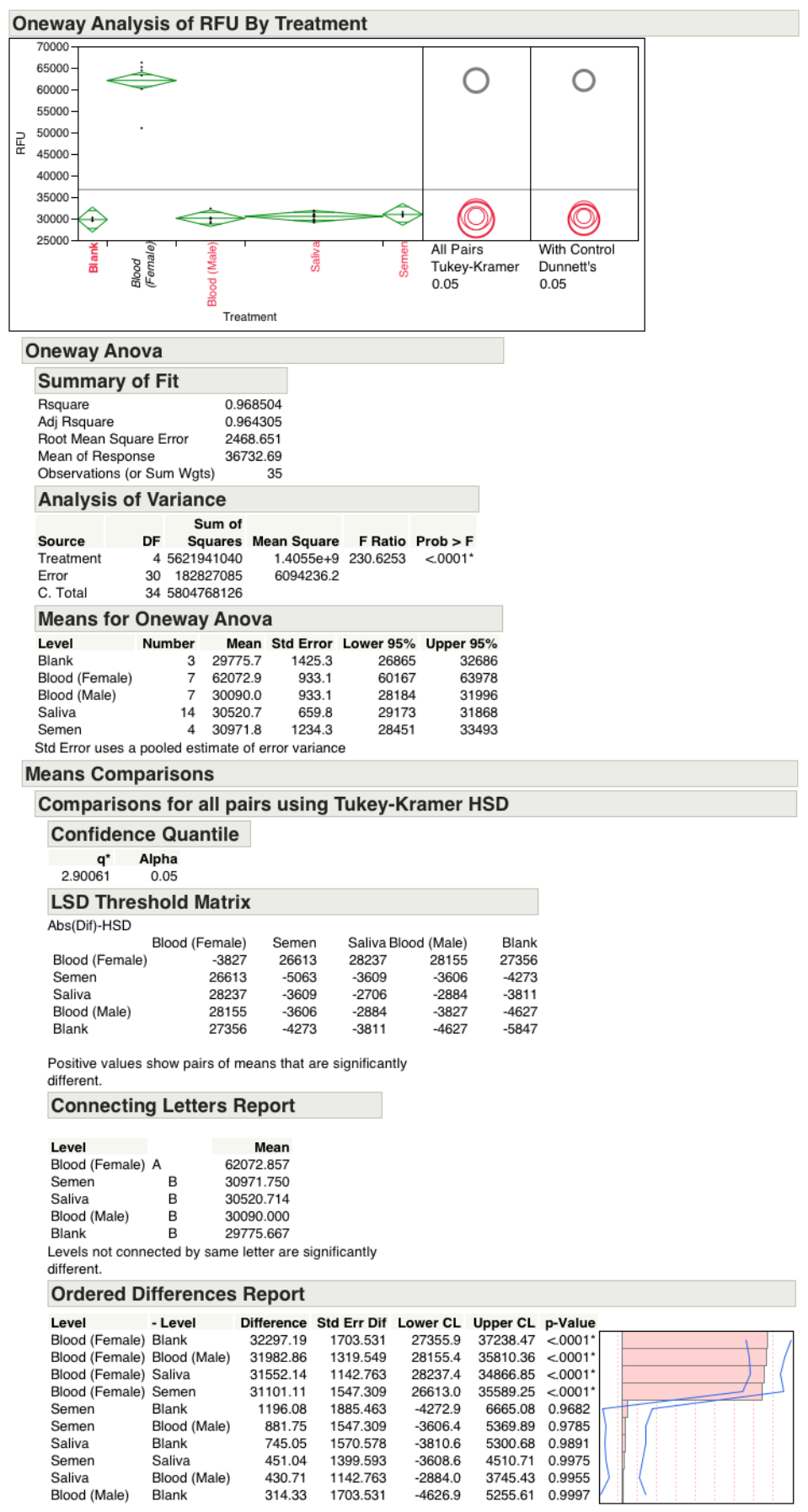

Comparisons with a control using Dunnett's Method

Control Group = Blank

Confidence Quantile

$\begin{array}{rr}\text { Idl } & \text { Alpha } \\ 2.50127 & 0.05\end{array}$

LSD Threshold Matrix

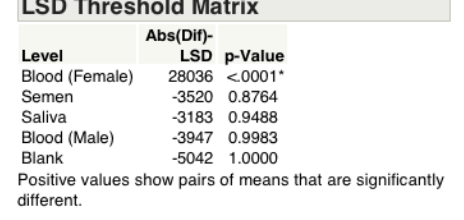

Figure 7: The JMP output for ANOVA analysis of the female-specific beacon testing data. 


\section{Discussion}

The purpose of this study was to continue development of a novel, confirmatory method of body fluid identification. The development of such a technique would reduce the amount of evidence retrieved while increasing the quality, and thus ease the workflow for evidence analysis in crime laboratories. The results of this study confirm that tissue-specific RNAs can be targeted to determine the biological make-up of a stain without the use of PCR. This study also shows that the sex of the person can be determined from a bloodstain, without the use of PCR or other time-consuming techniques $(28,29)$. The presented method, especially once optimized in multiplex, may help to reduce the amount of backlog that is currently plaguing crime laboratories nationwide.

The MB oligonucleotides were linked to their QDs using biotin-streptavidin interactions. The QDMBs were tested for proper conjugation using an assay in which quenching of the fluorophore was measured. It was determined that all MB oligonucleotides containing a quencher molecule had been correctly coupled to the corresponding QD. The fluorescence of certain QDMBs was more highly quenched than others, exhibiting a range of $97.4 \%$ to $48.3 \%$ reduction in fluorescence. As the QDMBs are not all equally quenched, there is room for further optimization. This variation is likely the result of natural differences in the fluorescence levels of the QDs, and the number of quenching MB probes attached to each QD (Figure 2). Each wavelength of QD has a different fluorescence intensity, which can be a challenge in quenching. Further refinement of the attachment chemistry to increase the quenching of the QDs will lead to an increase in the fluorescence above background detected when the QDMB meets its target RNA. 
Refinement of the assay may also increase the viability of multiplexing of the reactions. Understanding the functioning of the probes in singleplex is useful; however, a multiplex of reactions will shorten the amount of time necessary for sample analysis and reduce the amount of RNA necessary for analysis. There is also room for improvement on the basis of the binding of the QDMB to the target RNA. While RNA is generally visualized as a line, such as in Figure 1, in reality it tends to have secondary structure complicating this binding process. One possibility would be to heat the RNA and break hydrogen bonds holding the secondary structure; however, some preliminary work shows that heating the QDMB denatures the streptavidin-biotin linkage and eliminates the effectiveness of the QDMB.

Once optimized, there is room for further development and experimentation. Further study of the effect of aging of samples on the results could be performed to determine if there are reliable trends, and to determine what is causing the early drop-out of certain RNA species. If the trends are consistent across longer and larger studies, however, the results of the test could provide a rough estimate of the time of deposit of the stain. Past research using PCR-based techniques have shown that RNA can be detected in body fluid stains after longer periods of aging and can be used to determine the age of the stain $(30,31)$. Considering that the RNAs are known to exist for longer periods of time and are detectable using PCR, there may be some factor in the aging that affects the binding and fluorescence of the QDMB specifically. Also, there is the potential for the development of more QDMBs that could be incorporated into the technique to identify other tissue-specific RNA species of interest.

There are caveats to the sex-specificity beacons that can be controlled. Primarily, these are chromosomal disorders such as Turner's and Klinefelter's Syndromes. Turner's is an XO genotype, meaning a phenotypic female with a single $X$ chromosome, and occurs in 1 in 2500 
live births worldwide (32). A Turner female would not express XIST and thus would not test positive for our female-specific beacon; however, they would not test positive for the malespecific, either. A bloodstain that does not test positive for either sex-specific beacon could be logically surmised to be from a female with Turner's syndrome. Klinefelter's syndrome is a phenotypic male with multiple $\mathrm{X}$ chromosomes in addition to a Y chromosome, and occurs in 1 in 500 to 1000 live male births (33). A person with Klinefelter's would theoretically test positive for both sex-specific beacons and lead to the conclusion it is a mixed sample; later STR testing would confirm that it is in fact a single male donor.

We believe this technique offers multiple advantages in comparison to current presumptive and confirmatory tests for body fluid identification. Our technique can be used to process multiple samples in less than hour and does not require PCR. Without the requirement for PCR, the equipment, cost, and training required for the technique are all reduced. The cost of a multiplex reaction, combining the three body fluids with a human-specific beacon, would be approximately $\$ 10$ per sample for this technique. Including the sex-specific beacons would only be an increase of $\$ 1-2$ per sample. The technique provides a confirmatory answer to the identity of a body fluid or mixture of fluids, compared to at least two separate lab tests required to determine this currently. This may also be the first confirmatory technique for saliva that does not rely upon PCR. In addition, the technique can identify the sex of the depositor of a blood stain, which currently requires PCR analysis. This technique also does not degrade the DNA of a sample, as will some presumptive tests (8). Overall, this technique has the potential to be a highly useful tool in the reduction of the national DNA backlog and improving the value of RNA in forensic science. 


\section{Bibliography}

1. Nelson, M. (2011). Making sense of DNA backlogs, 2010: Myths vs. reality. National Institute of Justice, Office of Justice Programs, US Department of Justice.

2. Strom, K. J., \& Hickman, M. J. (2010). Unanalyzed evidence in law-enforcement agencies. Criminology \& Public Policy, 9(2), 381-404.

3. Virkler, K., \& Lednev, I. K. (2009). Analysis of body fluids for forensic purposes: from laboratory testing to non-destructive rapid confirmatory identification at a crime scene. Forensic Science International, 188(1), 1-17.

4. Danaher, P., White, R. L., Hanson, E. K., \& Ballantyne, J. (2015). Facile semi-automated forensic body fluid identification by multiplex solution hybridization of NanoString ${ }^{\circledR}$ barcode probes to specific mRNA targets. Forensic Science International: Genetics, 14, 18-30.

5. Gaensslen, R. E. (1983). Sourcebook in forensic serology, immunology, and biochemistry (pp. 112-15). US Department of Justice, National Institute of Justice.

6. James, S. H., Nordby, J. J. (Eds.). (2003). Forensic science: an introduction to scientific and investigative techniques. CRC Press, Boca Raton, FL.

7. Shaler, R. C. (2002). Modern forensic biology. Forensic Science Handbook, Prentice Hall, Upper Saddle River, NJ, 529-546.

8. De Almeida, J. P., Glesse, N., \& Bonorino, C. (2011). Effect of presumptive tests reagents on human blood confirmatory tests and DNA analysis using real time polymerase chain reaction. Forensic science international, 206(1), 58-61.

9. Alvarez, M., Juusola, J., \& Ballantyne, J. (2004). An mRNA and DNA co-isolation method for forensic casework samples. Analytical Biochemistry,335(2), 289-298.

10. Bowden, A., Fleming, R., \& Harbison, S. (2011). A method for DNA and RNA coextraction for use on forensic samples using the Promega DNA $\mathrm{IQ}^{\mathrm{TM}}$ system. Forensic Science International: Genetics, 5(1), 64-68.

11. Juusola, J., \& Ballantyne, J. (2007). mRNA Profiling for Body Fluid Identification by Multiplex Quantitative RT-PCR*. Journal of Forensic Sciences, 52(6), 1252-1262.

12. Hanson, E. K., Lubenow, H., \& Ballantyne, J. (2009). Identification of forensically relevant body fluids using a panel of differentially expressed microRNAs. Analytical biochemistry, 387(2), 303-314.

13. Fleming, R. I., \& Harbison, S. (2010). The development of a mRNA multiplex RT-PCR assay for the definitive identification of body fluids. Forensic Science International: Genetics, 4(4), 244-256.

14. Tyagi, S., \& Kramer, F. R. (1996). Molecular beacons: probes that fluoresce upon hybridization. Nature Biotechnology, (14), 303-8.

15. Jamieson, T., Bakhshi, R., Petrova, D., Pocock, R., Imani, M., \& Seifalian, A. M. (2007). Biological applications of quantum dots. Biomaterials, 28(31), 4717-4732.

16. Resch-Genger, U., Grabolle, M., Cavaliere-Jaricot, S., Nitschke, R., \& Nann, T. (2008). Quantum dots versus organic dyes as fluorescent labels. Nature methods, 5(9), 763-775.

17. Alivisatos, A. P. (1996). Perspectives on the physical chemistry of semiconductor nanocrystals. The Journal of Physical Chemistry, 100(31), 13226-13239.

18. Gene Link. (2011). Fluorescent Molecular Probes Product Profile.

19. Invitrogen. (2008). The future of fluorescence: Qdot nanocrystal technology. 
20. Yamamoto, M. L., Clark, T. A., Gee, S. L., Kang, J. A., Schweitzer, A. C., Wickrema, A., \& Conboy, J. G. (2009). Alternative pre-mRNA splicing switches modulate gene expression in late erythropoiesis. Blood, 113(14), 3363-3370.

21. Hu, S., Li, Y., Wang, J., Xie, Y., Tjon, K., Wolinsky, L., \& Wong, D. T. (2006). Human saliva proteome and transcriptome. Journal of Dental Research, 85(12), 1129-1133.

22. Sakurada, K., Ikegaya, H., Fukushima, H., Akutsu, T., Watanabe, K., \& Yoshino, M. (2009). Evaluation of mRNA-based approach for identification of saliva and semen. Legal Medicine (Tokyo, Japan), 11(3), 125-8. doi:10.1016/j.legalmed.2008.10.002

23. Mori, C., Nakamura, N., Welch, J.E., Shiota, K., Eddy, E.M., Testis-Specific Expression of mRNAs for a Unique Human Type 1 Hexokinase Lacking the Porin-Binding Domain. Molecular Reproduction and Development, 1996. 44: 14-22.

24. Jansen, R., Batista, S., Brooks, A. I., Tischfield, J. A., Willemsen, G., van Grootheest, G., \& Penninx, B. W. (2014). Sex differences in the human peripheral blood transcriptome. BMC genomics, 15(1), 33.

25. Plath, K., Mlynarczyk-Evans, S., Nusinow, D. A., \& Panning, B. (2002). Xist RNA and the Mechanism of X Chromosome Inactivation. Annual review of genetics, 36(1), 233 278.

26. Young, Stephanie T. RNA in Forensic Science Novel Techniques for Biological Evidence. Diss. West Virginia University, 2011.

27. Cady, N. C., Strickland, A. D., \& Batt, C. A. (2007). Optimized linkage and quenching strategies for quantum dot molecular beacons. Molecular and cellular probes, 21(2), 116124.

28. Li, S., Feng, T., Fu, L., Li, Z., Lou, C., Zhang, X., ... \& Cong, B. (2012). Pyrosequencing of a short fragment of the amelogenin gene for gender identification. Molecular biology reports, 39(6), 6949-6957.

29. Morikawa, T., Yamamoto, Y., \& Miyaishi, S. (2011). A new method for sex determination based on detection of SRY, STS and amelogenin gene regions with simultaneous amplification of their homologous sequences by a multiplex PCR. Acta Medica Okayama, 65(2), 113-122.

30. Anderson, S., Howard, B., Hobbs, G. R., \& Bishop, C. P. (2005). A method for determining the age of a bloodstain. Forensic science international, 148(1), 37-45.

31. Smith, T. L. (2010). Investigating the potential of RNA to be used in forensic casework analysis. MS Thesis. West Virginia University.

32. Bondy, Carolyn. "Turner Syndrome - Home." Turner Syndrome - Home. National Institutes of Health, n.d. Web. 07 July 2015.

33. "Klinefelter Syndrome." Genetics Home Reference. National Institutes of Health, n.d. Web. 07 July 2015. 


\section{Appendix 1: JMP Output}

\section{Semen-specific Test}

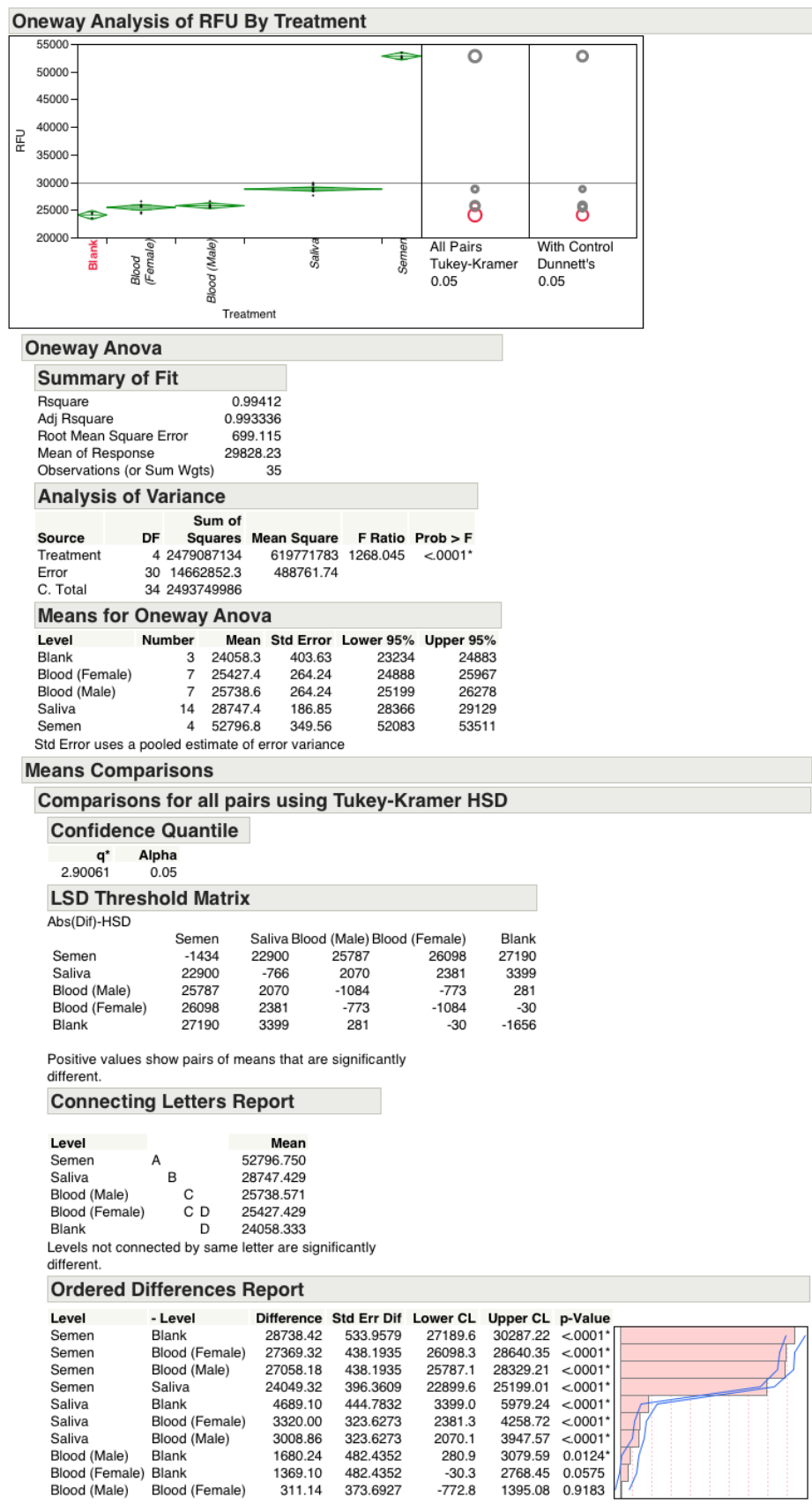

Comparisons with a control using Dunnett's Method

Control Group = Blank

Confidence Quantile

$\begin{array}{rr}\text { Idl } & \text { Alpha } \\ 50127 & 0.05\end{array}$

LSD Threshold Matrix

$\begin{array}{lrl} & \text { Abs(Dif)- } & \\ \text { LSD } & \text { p-Value } \\ \text { Level } & 27403<0001^{*} \\ \text { Semen } & & 3575<0001^{*}\end{array}$

$\begin{array}{lrl}\text { Semen } & 27403<0001 \\ \text { Saliva } & 3577<<0001 \\ \text { Sal } & <735 & 0.0048\end{array}$

$\begin{array}{llll} & 3577 & <0001^{\circ} \\ \text { Blood (Male) } & 473.5 & 0.0048^{\circ} \\ & 162.4 & 0.0234^{\circ}\end{array}$

$\begin{array}{llll}\text { Blood (Female) } & 162.4 & 0.0234^{\circ} \\ \text { Blank } & -1428 & 1.0000\end{array}$

Positive values show pairs of means that are significantly

different. 
Saliva-specific Test

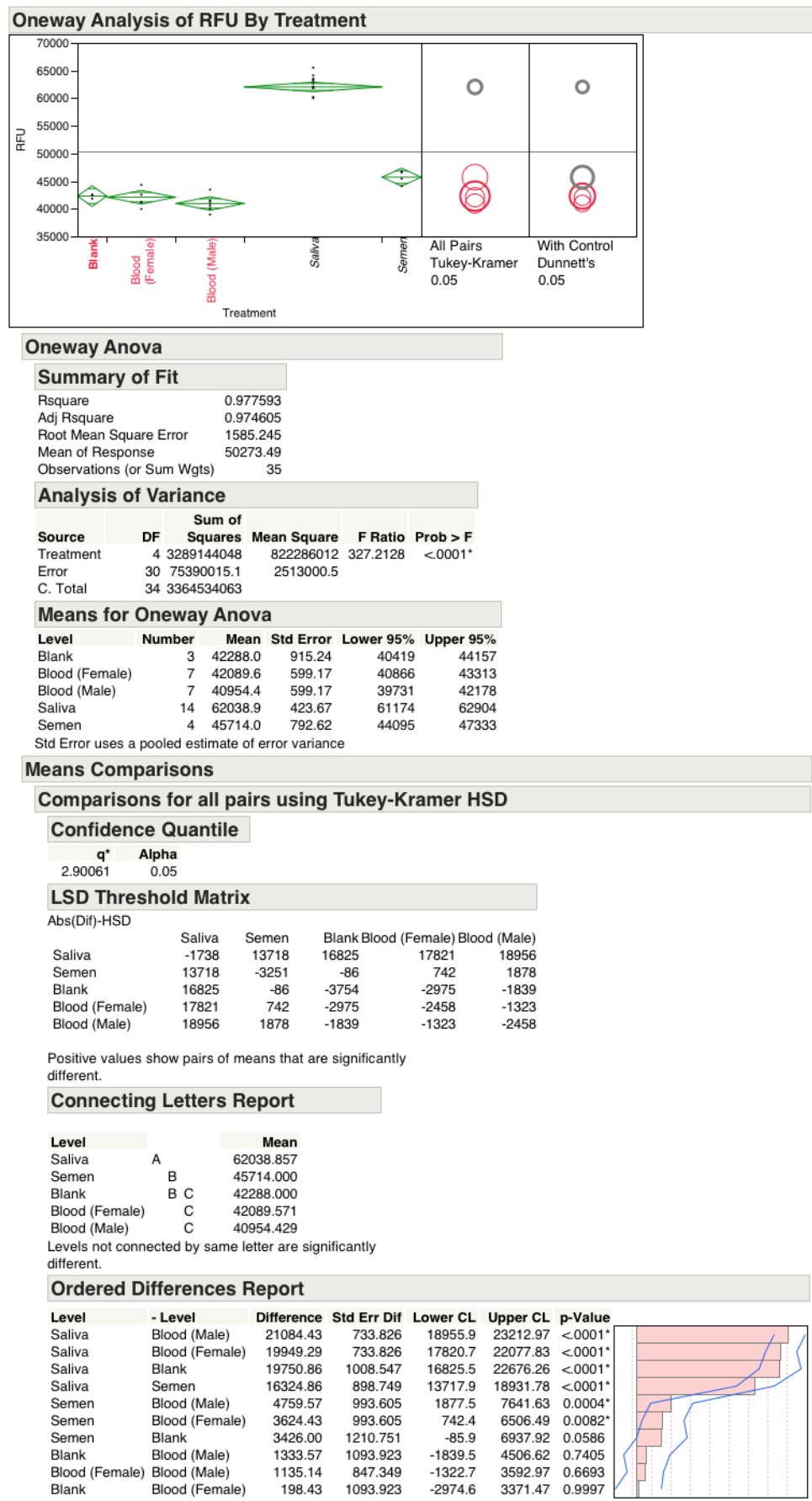

Comparisons with a control using Dunnett's Method

Control Group = Blank

Confidence Quantile

$\begin{array}{rr}\text { Idl } & \text { Alpha } \\ 2.50127 & 0.05\end{array}$

LSD Threshold Matrix

\begin{tabular}{lrl}
\multicolumn{4}{c}{ Abs(Dif)- } & \\
Level & LSD & p-Value \\
Saliva & 17228 & $<0001^{*}$ \\
Semen & 397.6 & $0.0239^{*}$ \\
Blank & -3238 & 1.0000 \\
Blood (Female) & -2538 & 0.9984 \\
Blood (Male) & -1403 & 0.4871 \\
Positive values show pairs of means that are significantly \\
different.
\end{tabular}




\section{Blood-specific Test}

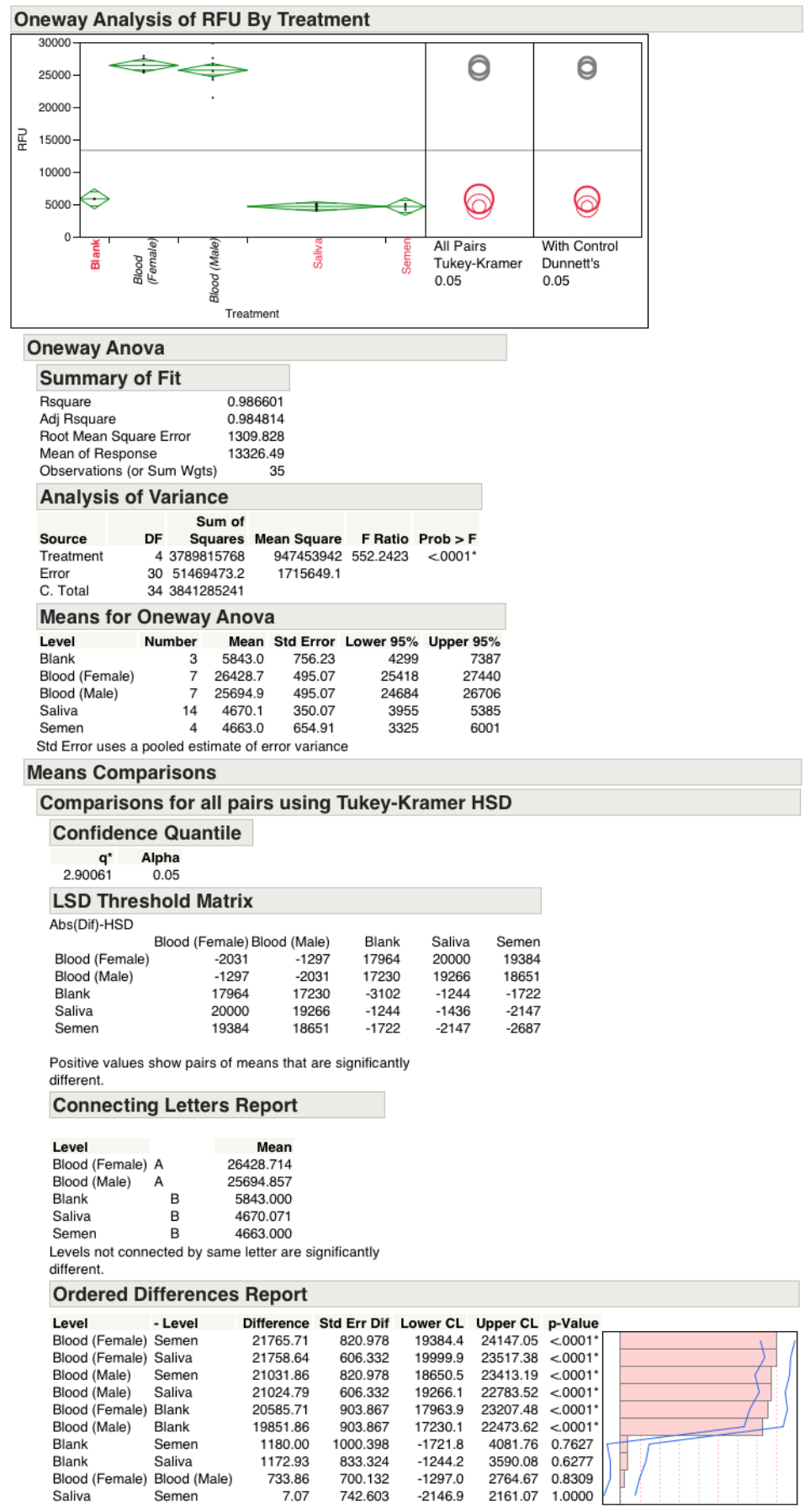

Comparisons with a control using Dunnett's Method

Control Group = Blank

Confidence Quantile

$\begin{array}{rr}\text { Idl } & \text { Alpha } \\ .50127 & 0.05\end{array}$

LSD Threshold Matrix

Abs(Dif)-

Level LSD p-Value

$\begin{array}{lll}\text { Blood (Female) } & 18325<0001 \\ \text { Blood (Male) } & 17591<0001^{*}\end{array}$

Blank $\quad-2675 \quad 10000$

$\begin{array}{lll}\text { Saliva } & -911 & 0.3747\end{array}$

$\begin{array}{lll}\text { Semen } & -911 & 0.3747 \\ \text { Sem } & 0.5127\end{array}$

Positive values show pairs of means that are significantly

different. 


\section{Male-specific Test}

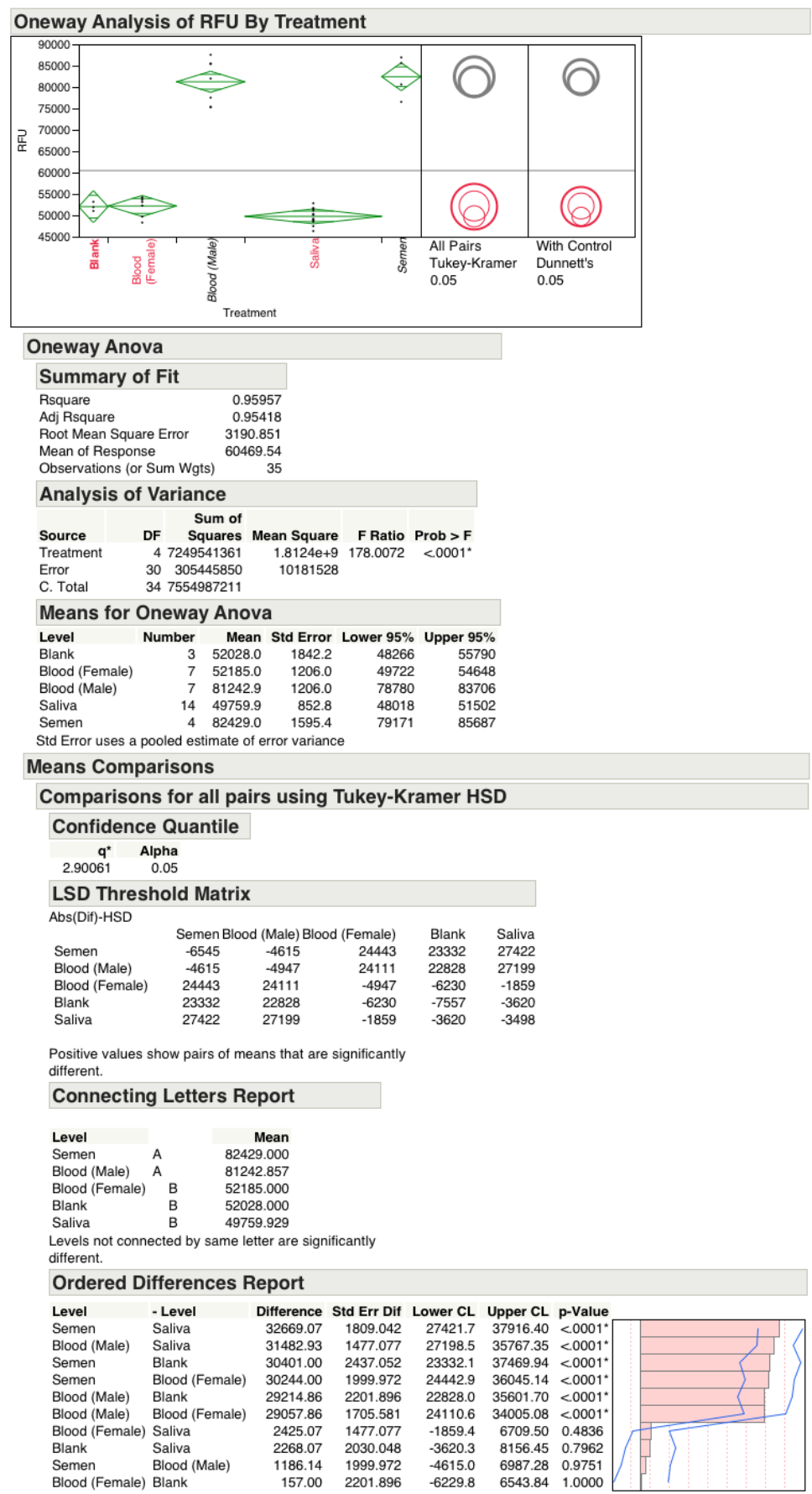

Comparisons with a control using Dunnett's Method

Control Group $=$ Blank

Confidence Quantile

$\begin{array}{rr}\text { Idl } & \text { Alpha } \\ .50127 & 0.05\end{array}$

LSD Threshold Matrix

$\begin{array}{ll} & \text { Abs(Dif)- } \\ \text { Level } & \text { LSD p-Value }\end{array}$

$\begin{array}{lll}\text { Semen } & 24305<0001^{*} \\ \text { Blood (Male) } & 23707<0001^{*}\end{array}$

$\begin{array}{lrr}\text { Blood (Male) } & 23707<0001{ }^{*} \\ \text { Blood (Female) } & -5351 & 1.0000\end{array}$

$\begin{array}{lll}\text { Blood (Female) } & -5351 & 1.0000 \\ \text { Blank } & -6517 & 1.0000\end{array}$

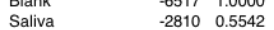

Positive values show pairs of means that are significantly

different. 
Female-Specific Test

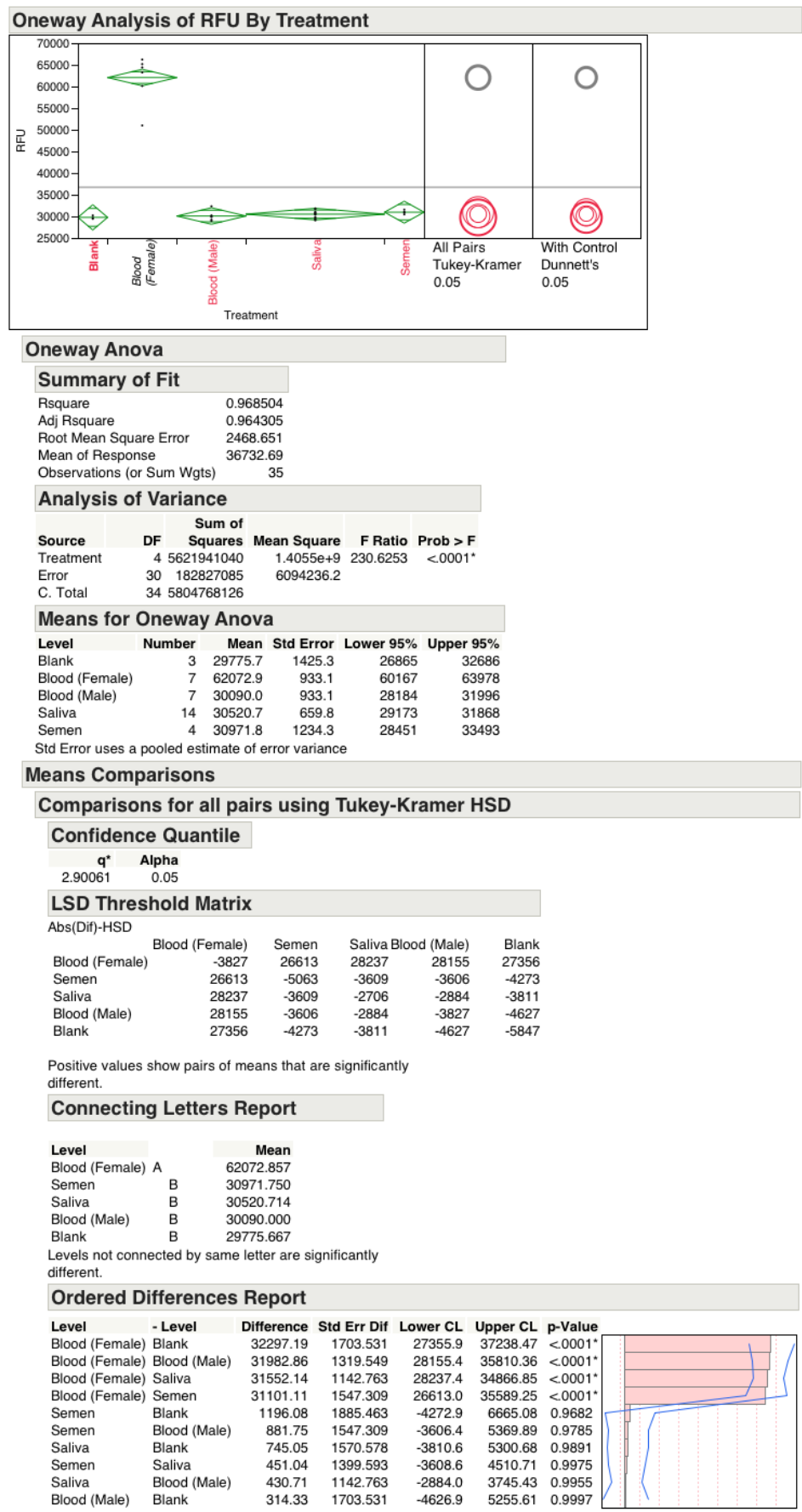

Comparisons with a control using Dunnett's Method

Control Group = Blank

Confidence Quantile

$\begin{array}{rr}\text { Idl } & \text { Alpha } \\ 2.50127 & 0.05\end{array}$

LSD Threshold Matrix

Abs(Dif)-

$\begin{array}{lll}\text { Level Abs(Dif)- } & \text { LSD p-Value } \\ \text { Blood (Female) } & 28036\end{array}$

Blood (Female) $\quad 28036<0001$.

$\begin{array}{lll}\text { Semen } & -3520 & 0.8764 \\ \text { Saliva } & -3183 & 0.9488\end{array}$

$\begin{array}{lll}\text { Blood (Male) } & -3947 & 0.9983\end{array}$

Positive values show pairs of means that are significantly

different. 
Human-Specific Test

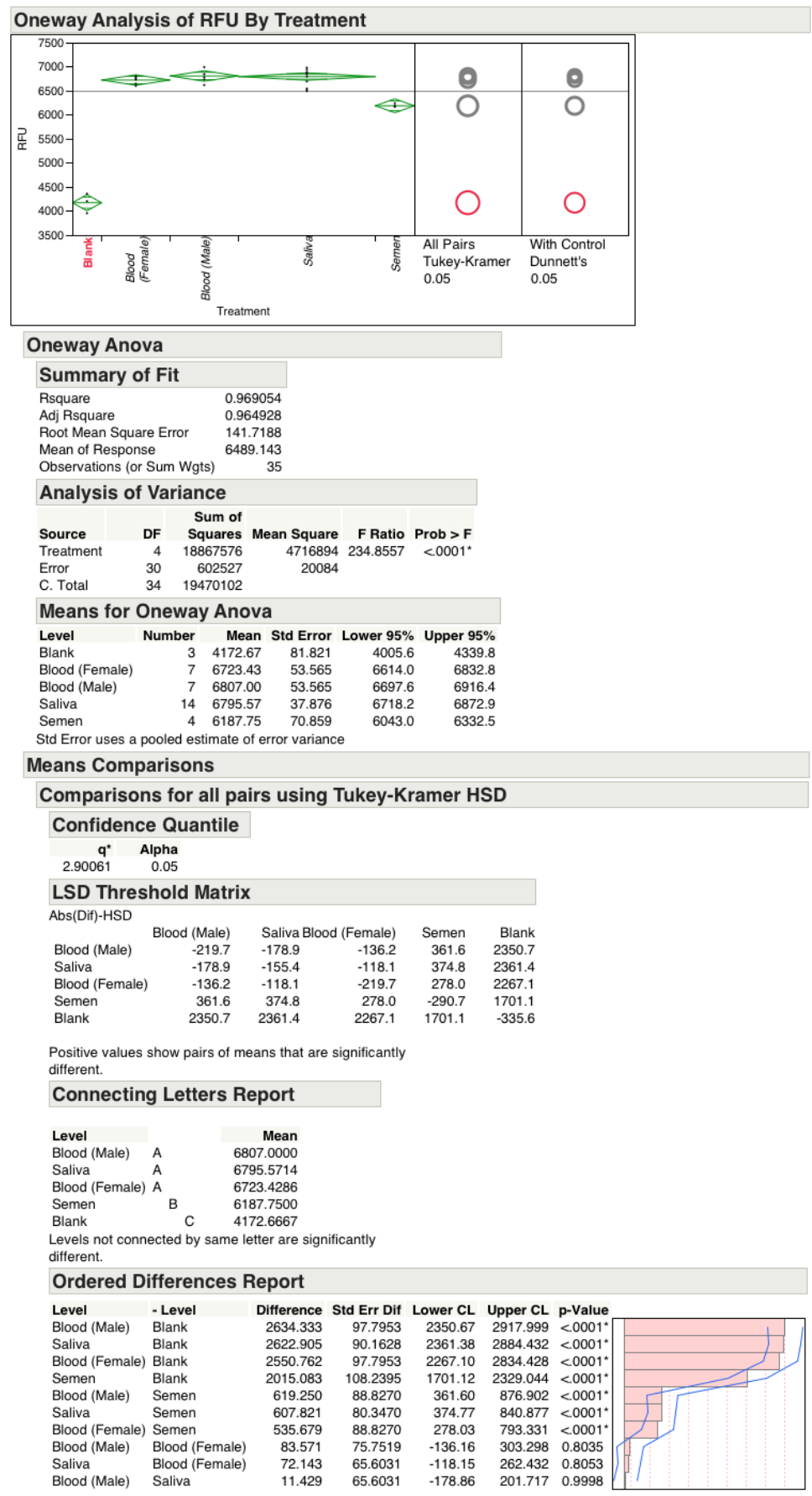

Comparisons with a control using Dunnett's Method

Control Group = Blank

Confidence Quantile

$\begin{array}{rr}\text { Idl } & \text { Alpha } \\ .50127 & 0.05\end{array}$

LSD Threshold Matrix

$\begin{array}{lll} & \text { Abs(Dif)- } \\ \text { Level } & \text { LSD -Value }\end{array}$

Blood (Male) $\quad 2390<0001^{*}$

$\begin{array}{lll}\text { Saliva } & 2397<0001^{*} \\ \text { Blood (Female) } & 2306<0001^{*}\end{array}$

$\begin{array}{lrll}\text { Blood (Female) } & 2306 & <.0001^{*} \\ \text { Semen } & 1744 & <.0001^{*} \\ \text { Blank } & -289 & 1.0000\end{array}$

Positive values show pairs of means that are significantly

different. 


\section{Aged Semen Test}

Oneway Analysis of RFU By Treatment

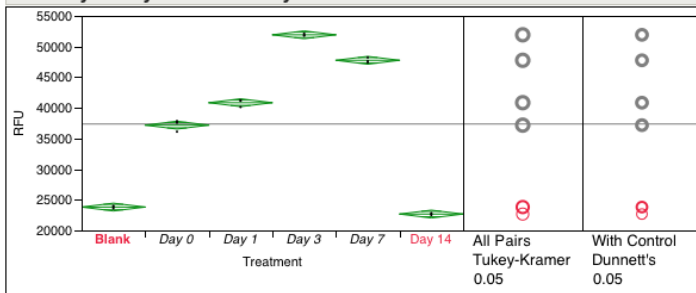

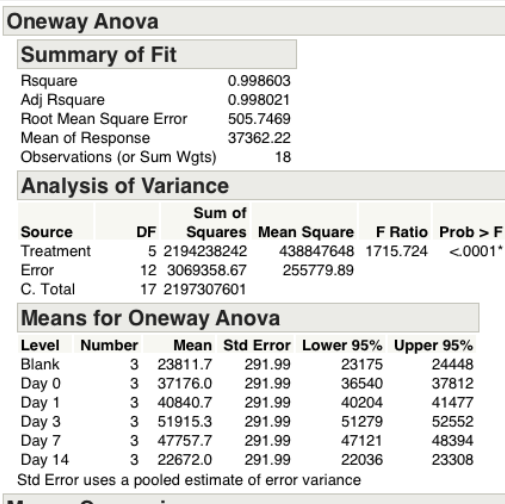

Means Comparisons

Comparisons for all pairs using Tukey-Kramer HSD

Confidence Quantile

$\begin{array}{rr}q^{*} & \text { Alpha } \\ 3.35886 & 0.05\end{array}$

LSD Threshold Matrix

Abs(Dif)-HSD

$\begin{array}{lrrrrrr}\text { Abs(Dif)-HSD } & \text { Day 3 } & \text { Day 7 } & \text { Day 1 } & \text { Day 0 } & \text { Blank } & \text { Day 14 } \\ \text { Day 3 } & -1387 & 2771 & 9688 & 13352 & 26717 & 27856 \\ \text { Day 7 } & 2771 & -1387 & 5530 & 9195 & 22559 & 23699 \\ \text { Day 1 } & 9688 & 5530 & -1387 & 2278 & 15642 & 16782 \\ \text { Day 0 } & 13352 & 9195 & 2278 & -1387 & 11977 & 13117 \\ \text { Blank } & 26717 & 22559 & 15642 & 11977 & -1387 & -247 \\ \text { Day 14 } & 27856 & 23699 & 16782 & 13117 & -247 & -1387\end{array}$

Positive values show pairs of means that are significantly

Connecting Letters Report

$$
\begin{aligned}
& \begin{array}{lr}
\text { Level } & \text { Mean } \\
\text { Day 3 A } & 51915.333
\end{array} \\
& \text { Day } 7 \text { B } \quad 47757.667 \\
& \begin{array}{lll}
\text { Day } 1 & C & 40840.667 \\
\text { Day } 0 & & 371760007
\end{array} \\
& \begin{array}{lll}
\text { Day 0 } & \text { D } & 37176.000 \\
\text { Blank } & \text { E } & 23811.667 \\
\text { Day } 14 & \text { E } & 22672000
\end{array} \\
& \text { Levels not connected by same letter are significantly }
\end{aligned}
$$

Ordered Differences Report

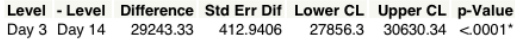

\begin{tabular}{lllllll} 
Day 3 Blank 28103.67 & 412.9406 & 27856.3 & 30630.34 & $<0001$ \\
\hline & 26716.7 & 29490.68 & $<0001^{*}$
\end{tabular} .

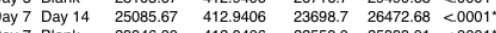

\begin{tabular}{lllllll} 
& & 22559.0 & 25333.01 & $<0001$ \\
\hline
\end{tabular}

\begin{tabular}{llllll} 
Day 1 Blank & 17029.00 & 412.9406 & 15642.0 & $18416.01<0001$ \\
\hline
\end{tabular}

$\begin{array}{llllll}\text { Day } 3 \text { Day } 0 & 14739.33 & 412.9406 & 13352.3 & 16126.34 & <0001\end{array}$

$\begin{array}{llllll}\text { Day } 0 \text { Day } 14 & 14504.00 & 412.9406 & 13117.0 & 15891.01<0001\end{array}$

\begin{tabular}{llllll} 
Day O Blank & 13364.33 & 412.9406 & 11977.3 & $14751.34<0001$ & $<00$ \\
\hline
\end{tabular}

$\begin{array}{llllllll} & \text { Day } 3 \text { Day } 1 & 11074.67 & 412.9406 & 9687.7 & 12461.68 & <0001\end{array}$

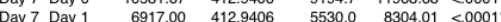

$\begin{array}{lllllll}\text { Day } 3 \text { Day } 7 & 4157.67 & 412.9406 & 2770.7 & 5544.68 & <0001\end{array}$

\begin{tabular}{llllll|} 
Day 1 Day 0 & 3664.67 & 412.9406 & 2277.7 & 5051.68 & $<0001$. \\
Blank Day 14 & 1139.67 & 412.9406 & -247.3 & 2526.68 & 0.1331
\end{tabular}

Comparisons with a control using Dunnett's Method

Control Group $=$ Blank

Confidence Quantile

$\begin{array}{rr}\text { Idl } & \text { Alpha } \\ 90130 & 0.05\end{array}$

LSD Threshold Matrix

Abs(Dif)-

$\begin{array}{lll}\text { Level } & \text { LSD p-Value } \\ \text { Devi } & 26906<0001\end{array}$

Day $7 \quad 22748<0001$

Day $1 \quad 15831<0001$

$\begin{array}{lll}\text { Day } 0 & 12166<0001 \\ \text { Blank } & -1198 & 10000\end{array}$

$\begin{array}{llll}\text { Blank } & -1198 & 1.0000 \\ \text { Day } 14 & -58.4 & 0.0640\end{array}$

Positive values show pairs of means that are significantly

different. 


\section{Aged Saliva Test}

Oneway Analysis of RFU By Treatment

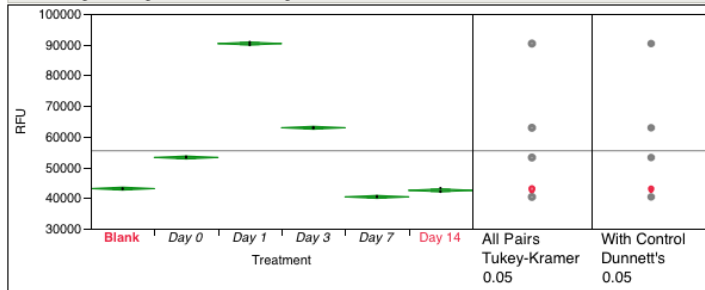

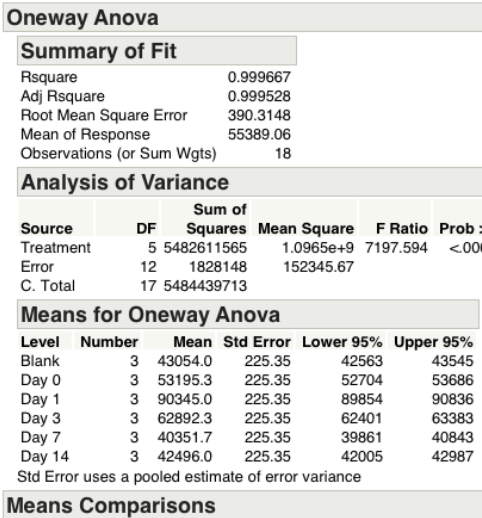

Comparisons for all pairs using Tukey-Kramer HSD

Confidence Quantile

$\begin{array}{rr}q^{*} & \text { Alpha } \\ 3.35886 & 0.05\end{array}$

LSD Threshold Matrix

Abs(Dif)-HSD

$\begin{array}{lrrrrrr}\text { Abs(Dif)-HSD } & \text { Day 1 } & \text { Day 3 } & \text { Day 0 } & \text { Blank } & \text { Day 14 } & \text { Day 7 } \\ \text { Day 1 } & -1070 & 26382 & 36079 & 46221 & 46779 & 48923 \\ \text { Day 3 } & 26382 & -1070 & 8627 & 18768 & 19326 & 21470 \\ \text { Day 0 } & 36079 & 8627 & -1070 & 9071 & 9629 & 11773 \\ \text { Blank } & 46221 & 18768 & 9071 & -1070 & -512 & 1632 \\ \text { Day 14 } & 46779 & 19326 & 9629 & -512 & -1070 & 1074 \\ \text { Day 7 } & 48923 & 21470 & 11773 & 1632 & 1074 & -1070\end{array}$

Positive values show pairs of means that are significantly
different.

Connecting Letters Report

$$
\begin{aligned}
& \begin{array}{lr}
\text { Level } & \text { Mean } \\
\text { Day 1 A } & 90345000
\end{array} \\
& \begin{array}{ll} 
& 90345.000 \\
\text { Day 3 B } & 62892.333
\end{array} \\
& \begin{array}{lll}
\text { Day 0 } & \text { C } & 53195.333 \\
\text { Blank } & &
\end{array} \\
& \begin{array}{lll}
\text { Blank } & \text { D } & 43054.000 \\
\text { Day } 14 & \text { D } & 42496.000 \\
\text { Da } 7 & & 40951.007
\end{array} \\
& \text { Levels not connected by same letter are significantly }
\end{aligned}
$$

Ordered Differences Report

Level - Level Difference Std Err Dif Lower CL Upper CL p-Value

$\begin{array}{llllllll}\text { Day } 1 & \text { Day } 7 & 49993.33 & 318.6907 & 48922.9 & 51063.77 & <0001\end{array}$

\begin{tabular}{lllllll} 
Day 1 & Day 14 & 47849.00 & 318.6907 & 46778.6 & 48919.44 & $<0001$ \\
Day 1 & Blank & 47291.00 & 318.6907 & 46220.6 & 48361.44 & $<0001$ \\
\hline Day & Day & 3149.67 & 38.907 & 36792 & 232 & $<001$
\end{tabular}

$\begin{array}{lllllll}\text { Day } 1 \text { Blank } & 47291.00 & 318.6907 & 46220.6 & 48361.44 & <0001\end{array}$

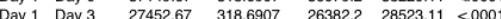

\begin{tabular}{lllllll}
\hline Day 3 & Day 7 & 272540.67 & 318.6907 & 21470.2 & $23611.11<0001$ & $<$
\end{tabular}

$\begin{array}{lllllll}\text { Day } 3 & \text { Day } 14 & 20396.33 & 318.6907 & 19325.9 & 21466.77<0001\end{array}$

\begin{tabular}{lllllll} 
Day 3 & Blank & 19838.33 & 318.6907 & 18767.9 & $20908.77<0001$ \\
\hline
\end{tabular}

\begin{tabular}{lllllll}
\hline Day 0 & Day 7 & 12843.67 & 318.6907 & 11773.2 & $13914.11<0001$
\end{tabular}

\begin{tabular}{lllllll} 
Day 0 Day 14 & 10699.33 & 318.6907 & 9628.9 & $11769.77<0001$ \\
\hline
\end{tabular}

$\begin{array}{llllll}\text { Day O Blank } & 10141.33 & 318.6907 & 9070.9 & 11211.77< & <0001\end{array}$

$\begin{array}{lllllll}\text { Blank Day } 7 & 2702.33 & 3186907 & 16261.9 & 3772.47 & <0001\end{array}$

\begin{tabular}{llllll}
\hline Day 14 Day 7 & 2144.33 & 318.6907 & 1073.9 & 3214.77 & $0.0002^{*}$
\end{tabular}

$\begin{array}{llllll}\text { Blank Day } 14 & 558.00 & 318.6907 & -512.4 & 1628.44 & 0.5274\end{array}$

Comparisons with a control using Dunnett's Method

Control Group $=$ Blank

Confidence Quantile

$\begin{array}{rr}\text { Idl } & \text { Alpha } \\ 2.90130 & 0.05\end{array}$

LSD Threshold Matrix

Abs(Dif)-

Level LSD p-Value

Day $3 \quad 18914<0001$.

Day $0 \quad 9217<0001$

$\begin{array}{lll}\text { Blank } & -925 & 1.0000 \\ \text { Day } 14 & -367 & 0.3268\end{array}$

Positive values show pairs of means that are significantly

different. 


\section{Aged Blood Test}

Oneway Analysis of RFU By Treatment
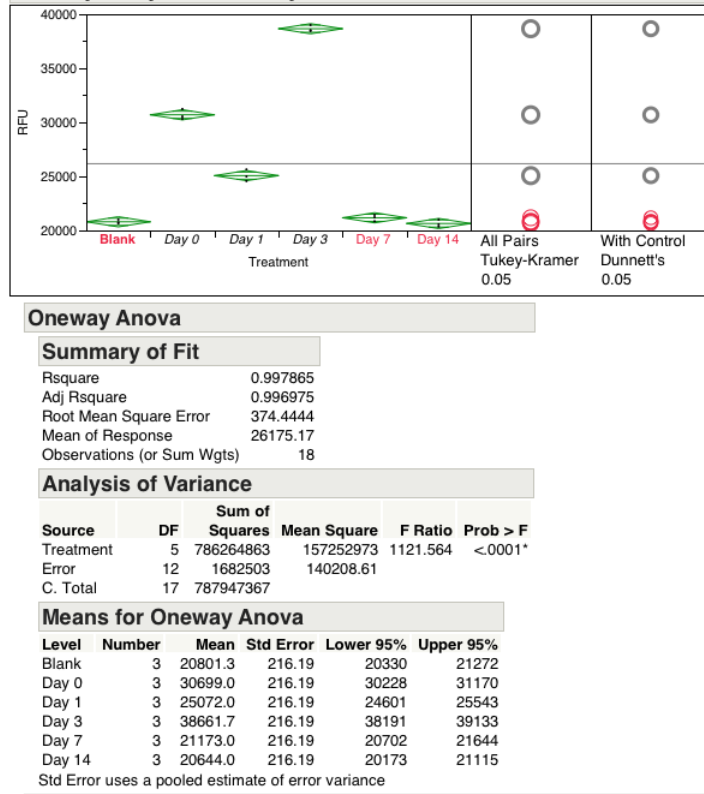

Means Comparisons

Comparisons for all pairs using Tukey-Kramer HSD

Confidence Quantile

$\begin{array}{rr}\mathbf{q}^{*} & \text { Alpha } \\ 3.35886 & 0.05\end{array}$

LSD Threshold Matrix

Abs(Dif)-HSD

$\begin{array}{lrrrrrr}\text { Abs(Dir)-HSD } & \text { Day 3 } & \text { Day 0 } & \text { Day 1 } & \text { Day 7 } & \text { Blank } & \text { Day 14 } \\ \text { Day 3 } & -1027 & 6936 & 12563 & 16462 & 16833 & 16991 \\ \text { Day 0 } & 6936 & -1027 & 4600 & 8499 & 8871 & 9028 \\ \text { Day 1 } & 12563 & 4600 & -1027 & 2872 & 3244 & 3401 \\ \text { Day 7 } & 16462 & 8499 & 2872 & -1027 & -655 & -498 \\ \text { Blank } & 16833 & 8871 & 3244 & -655 & -1027 & -870 \\ \text { Day 14 } & 16991 & 9028 & 3401 & -498 & -870 & -1027\end{array}$

Positive values show pairs of means that are significantly

Connecting Letters Report

$$
\begin{aligned}
& \begin{array}{lr}
\text { Level } & \text { Mean } \\
\text { Day 3 A } & 38661.667
\end{array}
\end{aligned}
$$

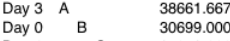

$$
\begin{aligned}
& \text { Day } 1 \text { C } 25072.000 \\
& \text { Day } 7 \text { D } 21173.000 \\
& \begin{array}{lll}
\text { Blank } & \text { D } & 20801.333 \\
\text { Day 14 } & \text { D } & 20644.000
\end{array} \\
& \text { mignificantly }
\end{aligned}
$$

Ordered Differences Report

Level - Level Difference Std Err Dif Lower CL Upper CL p-Value

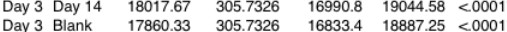

\begin{tabular}{lllllll}
\hline Day 3 Day 7 & 17488.67 & 305.7326 & 16461.8 & 18515.58 & $<0001$ \\
\hline & 1359.67 & 3057326 & 125628 & 14615.58 & $<0001$.
\end{tabular}

$\begin{array}{llllll}\text { Day } 3 \text { Day } 1 & 13589.67 & 305.7326 & 12562.8 & 14616.58<0001 & \end{array}$

\begin{tabular}{llllll} 
Day 0 Day 14 & 10055.00 & 305.7326 & 9028.1 & $11081.91<0001$ \\
\hline
\end{tabular}

\begin{tabular}{lllllll} 
Day 0 Blank & 9897.67 & 305.7326 & 8870.8 & 10924.58 & $<0001$ \\
\hline
\end{tabular}

$\begin{array}{llllllll} & \text { Day 0 Day } 7 & 9526.00 & 305.7326 & 8499.1 & 10552.91<0001\end{array}$

$\begin{array}{lllllll} & 7962.67 & 305.7320 & 6935.8 & 8589.58 & <0014\end{array}$

$\begin{array}{llllllll}\text { Day } 1 \text { Day } 14 & 4428.00 & 305.7326 & 3401.1 & 5454.91<001 & <001\end{array}$

$\begin{array}{lllllll}\text { Day } 1 \text { Blank } & 4270.67 & 305.7326 & 3243.8 & 5297.58 & <0001 \\ \end{array}$

$\begin{array}{llllll}\text { Day } 1 \text { Day } 7 & 3899.00 & 305.7326 & 2872.1 & 4925.91<0001\end{array}$

\begin{tabular}{llllll} 
Day 7 Day 14 & 529.00 & 305.7326 & -497.9 & 1555.91 & 0.5390 \\
\hline
\end{tabular}

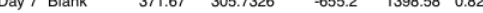

Comparisons with a control using Dunnett's Method

Control Group $=$ Blank

Confidence Quantile

$\begin{array}{rr}\text { Idl } & \text { Alpha } \\ 2.90130 & 0.05\end{array}$

LSD Threshold Matrix

Abs(Dif)-

$\begin{array}{ll}\text { Level } & \text { ALS } \\ \text { Lay } 3 & 16973<<0001^{*}\end{array}$

Day $0 \quad 9011<0001$

$\begin{array}{llll}\text { Day } 1 & 3384<0001 \\ \text { Day } 7 & 515 & 0.0636\end{array}$

Blank $\quad-887 \quad 10000$

Day $14 \quad-730 \quad 0.9778$

Positive values show pairs of means that are significantly

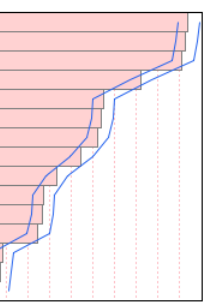


Aged Male-specific Test
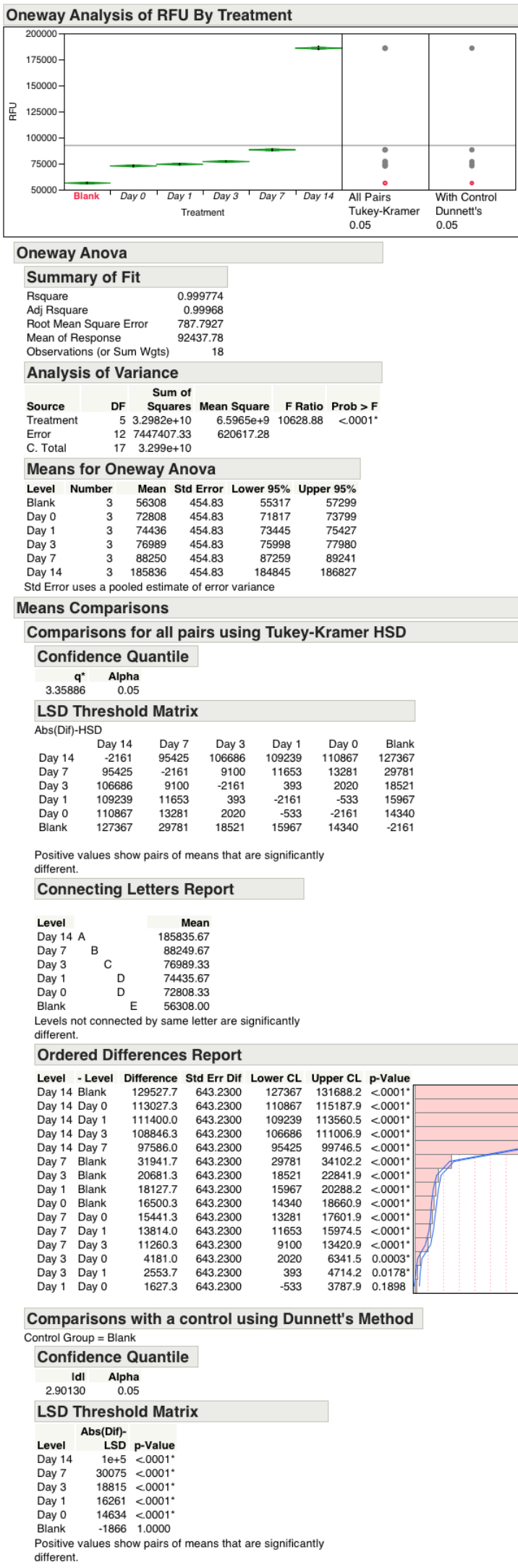

Comparisons with a control using Dunnett's Method

Control Group = Blank

Confidence Quantile

$\begin{array}{rr}\text { Idl } & \text { Alpha } \\ 2.90130 & 0.05\end{array}$

LSD Threshold Matrix

Level Abs(Dif)-

$\begin{array}{lll}\text { Level } & \text { LSD p-Value } \\ \text { Day } 14 & 1 \mathrm{e}+5<0001\end{array}$

$\begin{array}{lrl}\text { Day } 14 & 1 e+5 & <0001 \\ \text { Day } 7 & 30075 & <0001\end{array}$

Day $3 \quad 18815<0001$

Day $116261<0001$.

Day $0 \quad 14634<0001$

Blank $\quad-1866 \quad 1.0000$

Positive values show pairs of means that are significantly

different. 
Aged Female-specific Test

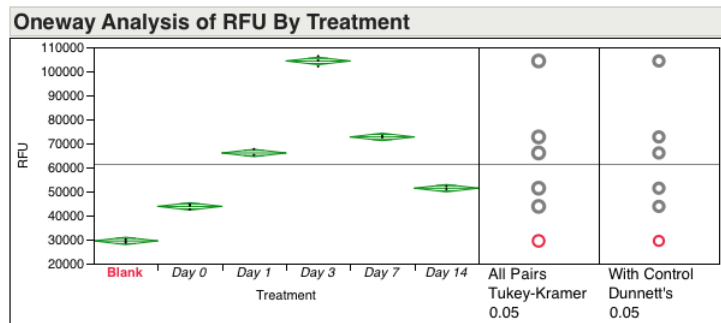

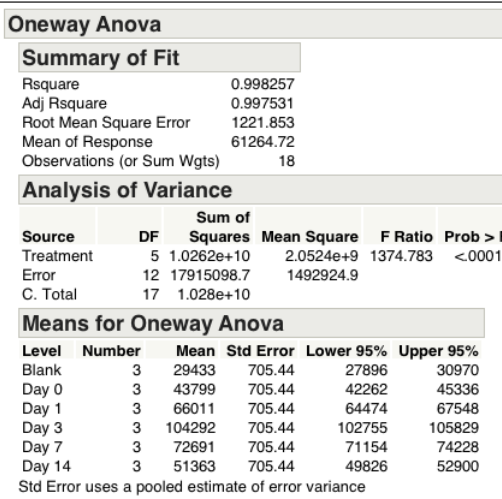

Means Comparisons

Comparisons for all pairs using Tukey-Kramer HSD

Confidence Quantile

$\begin{array}{rr}\mathbf{q}^{*} & \text { Alpha } \\ 3.35886 & 0.05\end{array}$

LSD Threshold Matrix

Abs(Dif)-HSD

$\begin{array}{lllllll}\text { Day } 3 & \text { Day } 3 & \text { Day } 7 & \text { Day } 1 & \text { Day } 14 & \text { Day } 0 & \text { Blank }\end{array}$

$\begin{array}{lrrrrrr}\text { Day } 7 & 28250 & -3351 & 33929 & 49578 & 57141 & 71508 \\ & & 33297 & 25540 & 39907\end{array}$

\begin{tabular}{lrrrrrr} 
Day 1 & 34930 & 3329 & -3351 & 11297 & 18861 & 33227 \\
\hline & Day 14 & 49578 & 17977 & 11297 & -3351 & \\
\hline
\end{tabular}

\begin{tabular}{lllllll} 
Day 14 & 49578 & 17977 & 11297 & -3351 & 4212 & 18579 \\
Day 0 & 57141 & 25540 & 18861 & 4212 & -3351 & 11015 \\
\hline & 71508 & 39907 & 33227 & 18579 & 1 &
\end{tabular}

Positive values show pairs of means that are significantly

Connecting Letters Report

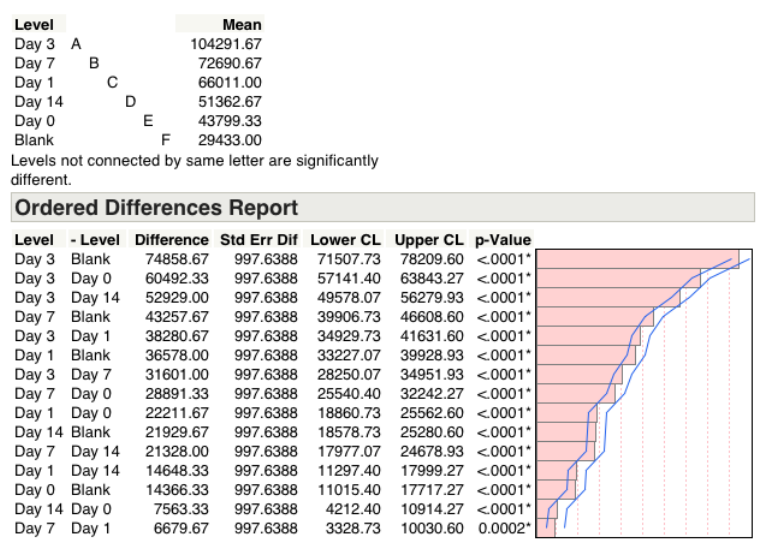

Comparisons with a control using Dunnett's Method

Control Group = Blank

Confidence Quantile

$\begin{array}{rr}\text { Idl } & \text { Alpha } \\ 90130 & 0.05\end{array}$

LSD Threshold Matrix

Abs(Dif)-

$\begin{array}{lrl}\text { Level } & \begin{array}{r}\text { ALS } \\ \text { LS }\end{array} \\ \text { Day } 3 & 71964 & <0001^{*}\end{array}$

Day $7 \quad 40363<0001$

Day $1433684<0001$

Day $0 \quad 11472<0001$

Blank $-2894 \quad 1.0000$

Positive values show pairs of means that are significantly

different. 